\title{
CONSERVATION AND REFUNCTIONING OF A TRADITIONAL HOUSE IN THE VILLAGE OF MUSTAFAPASA (SINASOS) IN THE CAPPADOCIA REGION ${ }^{1}$
}

\section{KAPADOKYA MUSTAFAPAŞA (SINASOS) KÖYÜNDE YER ALAN YAP- ININ KORUNMASI VE YENIDEN ISŞLEVLENDİRILMESI}

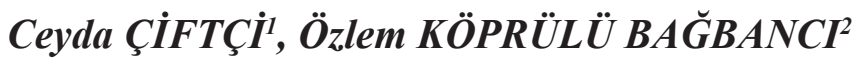 \\ ${ }^{1}$ Bursa Cultural Assets Protection Regional Board, Bursa / Turkey \\ ${ }^{2}$ Uludağ University, Faculty of Architecture Department of Architecture, Bursa / Turkey
}

0000-0003-0148-6295, $0000-0001-9050-4488^{2}$

Öz: Amaç: UNESCO Dünya Miras Listesi'nde yer alan Kapadokya bölgesi kendine özgü yapım tekniği, plan ve malzeme özellikleri bakımından özel bir öneme sahiptir. Mustafapaşa'da bulunan tescilli yapının korunması ve yeniden işlevlendirilmesine yönelik gerçekleștirilen çalışmalar evrensel koruma ilkeleri çerçevesinde ele alınmıştır. Yöntem: Çalışma; yapıyla ilgili olarak kapsamlı bir belgeleme çalışmas1, mimari ve tarihi özelliklerinin değerlendirilmesi, yapının mevcut durumu, yapıda görülen bozulmalar, restitüsyon, restorasyon ve son olarak ișlevlendirme projelerinin hazırlanmasını içermektedir. Bulgular: Bölgede bulunan kayaoyma yaşama alanları, bölgedeki güvenliğin sağlanmasıyla birlikte, önlerine eklenen yığma yapılarla bütünlük oluşturarak karakteristik bir özellik kazanmıştır. Mustafapaşa'nın merkezinde bulunan ve bütünlüğünü koruyan yapının mimariözellikleri, kültürel ve ekonomik değeri yapıyı önemli ve değerli kı1maktadır. Sonuç: Yapının yaşatılabilmesi için verilecek olan işlev önemlidir. Bu nedenle çalışmada 1999 tarihli ICOMOS Geleneksel Mimari Miras Tüzüğü ilkeleri ve 2013 tarihli ICOMOS Türkiye Mimari Mirası Koruma Bildirgesi ilkeleri yol gösterici olmuştur. Yapının korunması ve yaşatılması için gösterilen çaba; bölgede bulunan diğer kültür varlıklarının korunması için de örnek oluşturacaktır.

Anahtar Kelimeler: Mustafapaşa, Kapadokya, Kayaoyma, Koruma
Abstract: Purpose: The Cappadocia region located on the UNESCO World Heritage List has a special significance with respect to its distinct construction techniques, plan and material characteristics. The research of the study is to prepare a conservation and refunctioning project of a registered construction on private property in the context of universal conservation principles. Method: The study includes comprehensive documentation of the building, evaluation of architectural, historical features, the condition of fabric, the causes of deterioration, the restitution, the evaluation and finally the restoration project and refunctioning. Findings: The carved rock living quarters in the Cappadocia region are recognized as unique due to the integrity of the stacking structures attached over time to the provision of security in the region. The architectural features of the structure located in the centre of the village of Mustafapaşa village preserve the integrity of the structure and, more importantly, enhance the cultural and economic value of this treasured structure. Conclusion: As the refunctioning of a cultural heritage is important for the survival of the structure, the principles of the ICOMOS Traditional Architectural Heritage Regulations of 1999 and the Declaration of Conservation of ICOMOS Turkey's Architectural Heritage of 2013 are the guiding principles in the present study. Consequently, the efforts exerted for conservation and survival of the building also serve as an example for the preservation of other cultural assets in the region.

Key Words: Mustafapaşa, Cappadocia, Carved Rock, Conservation

Doi: $10.17365 /$ TMD.2018.1.1

(1) Responsible Author: Özlem KÖPRÜLÜ BAĞBANCI, Uludağ University, Faculty of Architecture, Department of Architecture, Bursa / Türkiye, ozlemkoprulu@yahoo.com, Geliş Tarihi: Received: 14.12.2018 - Kabul Tarihi: Accepted: 22.04.2017 Makalenin Türü: Typeofarticle (Araştırma-Inceleme / Research Review) Çıkar Çatı̧̧ması - Conflict of Interest: Yok/None "Etik Kurul Raporu Yok-None of Ethics Commit 


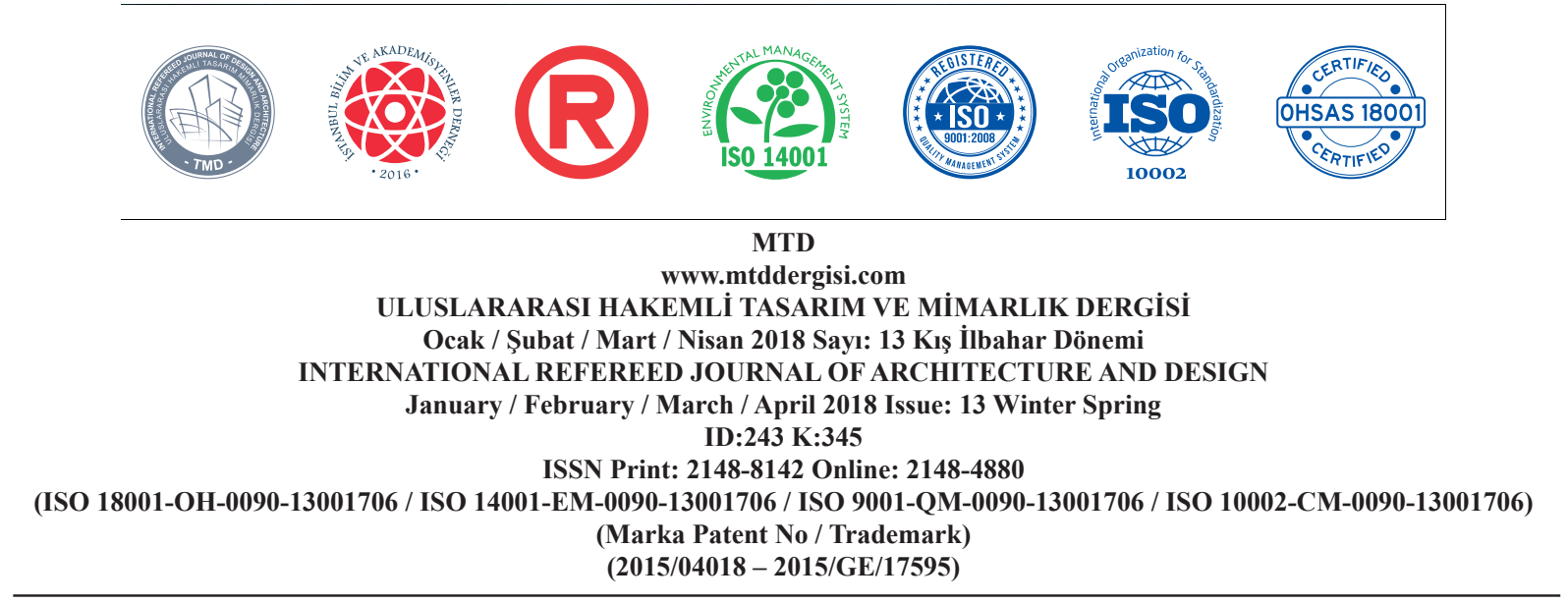

\section{INTRODUCTION}

The carved rock living quarters in the Cappadocia region offer a unique characteristic due to the integrity of the stacking structures that have been attached, over time to the provision of security in the region. According to the construction system, the housing typology consists of three forms, namely a carving system, a semi-carved-half masonry system, and a masonry system (Erençin, 1979: 54). An unusual quality of the carved rock formation in the region its ability to multiply and expand. However, these houses located on the valley slopes or on the fairy chimneys, called "carved houses" have no specific typology. The ventilation problem in these houses was solved by adding vertical interior ventilation pipes to minimize heat loss in the winter (Stea et al., 1993). "Semi-carved-half-masonry houses" those housed that are formed by building additional units to be carved rock units based on necessity. The carved rock residential buildings constructed on plain terrain or leaning on a slope were used as barns, warehouses and kitchen units, and as such they were allocated for provisions. The living quarters were located with in the masonry units. Places of iwan were created in the facades and courtyards of the semi-carved/semi-masonry houses. "Masonry houses were generally two storey" structures following the design of traditional houses. The ground floors was allocated for amenities and wet areas, while the upper floor was for sofas and living rooms. In the masonry housing typology, rich plan schemes and ornamental facades are the significant characteristics.

The book titled "Sinasos, Mübadeleden Önce Bir Kapadokya Kilisesi" by the famous Cappadocian historian Evangelia Balta and published in 2007 is one of the most important reference sources for this thesis. In addition, masters theses such as "Construction Techniques of Traditional Houses in Nevşehir; Case Study on Ürgüp, Mustafapaşa and İbrahimpaşa", completed at Middle East Technical University, Graduate School of Natural and Applied Sciences by Funda Solmaz in 2013 and "Mustafapaşa-Haralambos Sultanidis Evi Restorasyon Projesi" by Nevin Esin Tekin completed in 2009 at Istanbul Technical University, Graduate School of Natural and Applied Sciences are comprehensive and important studies that can be used to investigate the construction technique of traditional Nevşehir houses can benefit the conservation works in the region. Majority of the studies deal with the houses which were transformed into touristic facilities. Most remarkable works include Abdullah Erençin's PhD dissertation “Kapadokya Yerel Konutlarında Turizme Yönelik Yenileme Çalışmalarına Bir Yaklaşım” "prepared at ITU in 1979; Saba Tatar Akman's masters thesis "The Preservation and Rehabilitation 


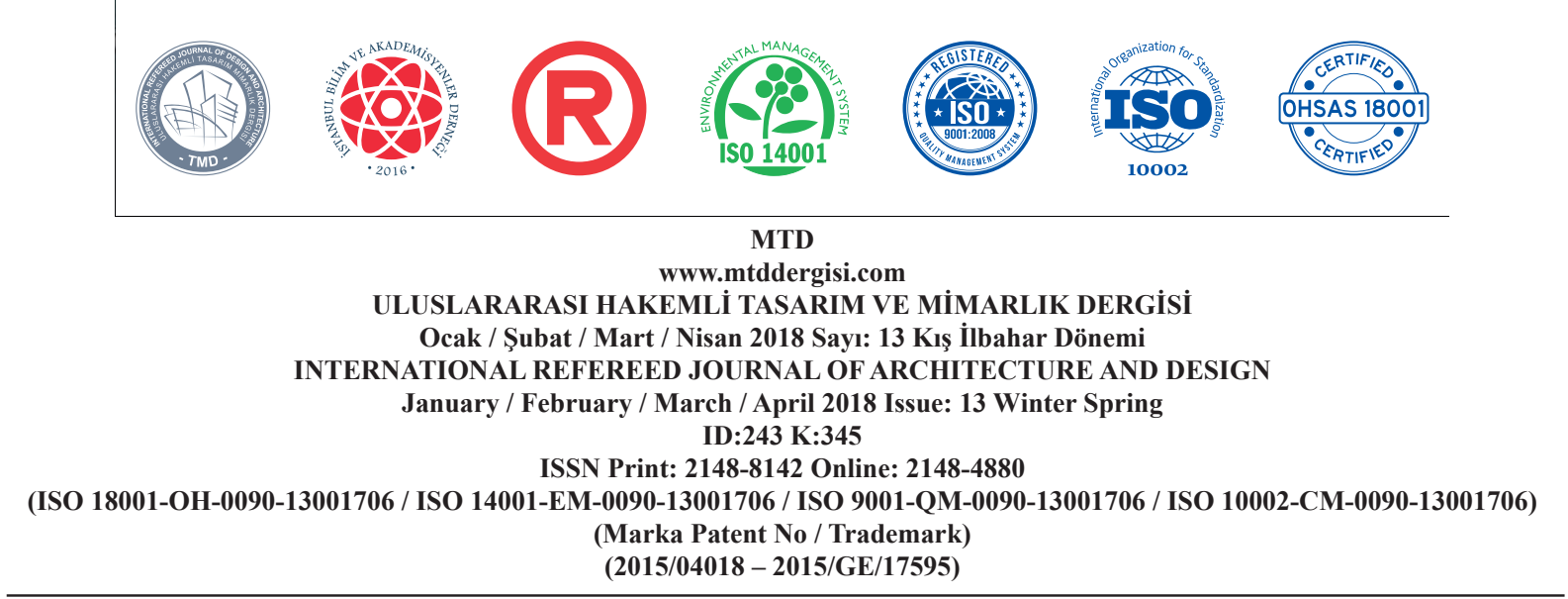

Project of 'Yeni Mahalle', Mustafapaşa" prepared at METU in 1985 and Demet Ulusoy Binan's “Güzelyurt örneğinde, Kapadokya Bölgesi Ylğma Taş Konut Mimarisinin Korunması İçin Bir Yöntem Araştirmasi”" a $\mathrm{PhD}$ dissertation prepared at YTU in 1994.

The village of Mustafapaşa (Sinasos) is located on the Ürgup-Kayseri highway six $\mathrm{km}$ south of the Ürgüp district of Nevşehir. Mustafapaşa is among the most developed and successful villages in the Cappadocia region. Mustafapaşa village, which is wellsuited for settlement was formed by the regional material of volcanic ignimbrite rocks that were carved horizontally and vertically have created rooms in the rocks that open toward the valley slopes (Roides, 1985). These characteristics made life in the region easier (Balta, 2007: 50).

\section{PURPOSE}

Mustafapaşa with its rapidly developing culture and its increase in tourism due to its historical features, is one of the most exceptional settlements in the of Cappadocia region. However the success of the conservation in the area depends on the quality of those projects and their applications of those projects. To preserve and maintain the structure in the best possible way and in accordance with the universal preservation decisions, it was determined to modify its function and pass it on to future generations. Accordingly all the works conducted for the conservation and preservation of the traditional buildings in the village of Mustafapaşa contribute to the increase in the importance of other buildings in the village and serve as an example for the preservation of other buildings and settlements.

\section{SCOPE}

The study includes comprehensive documentation of the building, evaluation of architectural, historical features, the condition of fabric, the causes of deterioration, the restitution, the evaluation and finally the restoration project and refunctioning. The structure that is the subject of this particular endeavour has current cultural and economic value. Within the scope of the cultural values are its values related to documentation, originality and uniqueness. Within the scope of current economic values are its economic value, functional value, educational value, social and political value (Feilden et al., 1998).

\section{METHOD of the STUDY}

The measurements of the structure that was the focus of this study were taken with a total station measuring instrument and the data obtained was transferred to a computer. History of the structure as well as its structural properties and construction techniques and building materials were investigated. Structural problems, material decay and deteriorations 


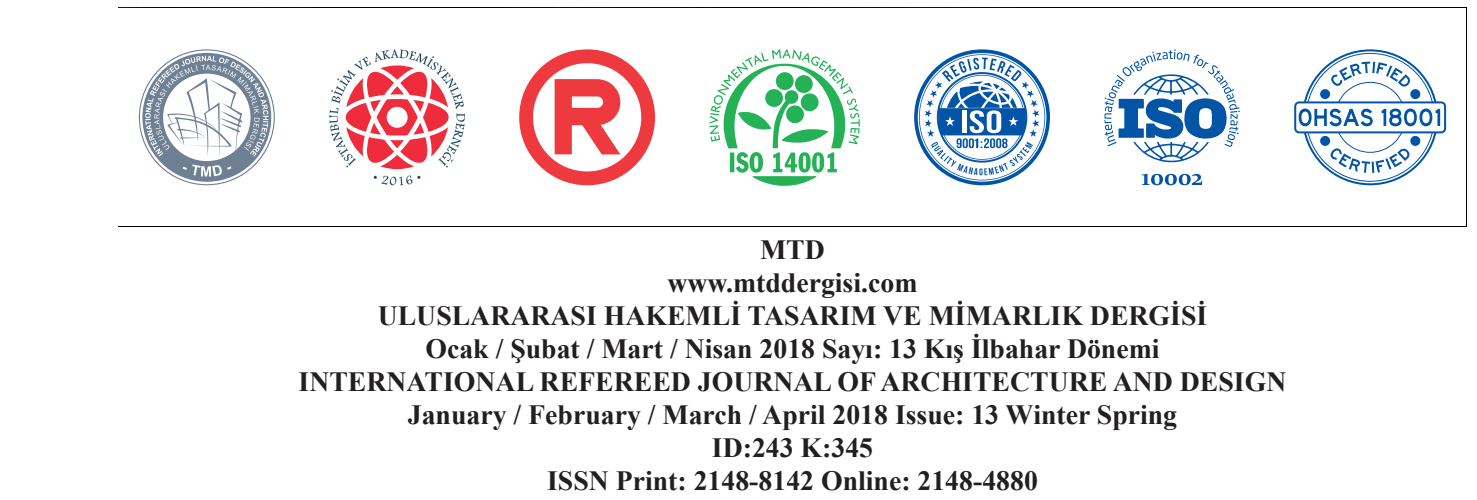

(ISO 18001-OH-0090-13001706 / ISO 14001-EM-0090-13001706 / ISO 9001-QM-0090-13001706 / ISO 10002-CM-0090-13001706)

(Marka Patent No / Trademark)

$(2015 / 04018-2015 / G E / 17595)$

were detected. As a result of the traces from the structure, comparative studies and all studies obtained from the archives, information was obtained regarding the original state of the building. The suggestions on the phases of the building and the restitution projects were prepared. At last in accordance with all these data, restoration proposal including the interventions and refunctioning of the building was provided after the evaluation of the building.

\section{THE RESEARCH PROBLEM}

The most important challenge facing this study is that the structures with historical value have been disappearing over time due to a variety of factors. The building is an irreplaceable cultural asset not only for its historical, aesthetic, architectural and documentary values but also a part of the urban settlement. Accordingly, all information related to the building has to be transfererred to the future in the context of universal conservation principles.

\section{THEORETICAL FRAMEWORK}

The Cappadocia region and Göreme National Park were added on 6 December 1985 to the UNESCO World Heritage List as natural and cultural heritage sites ${ }^{1}$. With the region entering the world heritage list, its impor-

1 http://www.kulturvarliklar1.gov.tr/TR,44423/ dunya-miras-listesi.html tance increased even more. The Nevşehir Mustafapaşa Conservation Development Plan was approved by the Regional Board for the Preservation of Cultural and Natural Assets dated 15.04.2004 and numbered 2620 (Archive of Nevşehir Cultural Heritage Conservation District Committee). Mustafapaşa is a very important settlement as "a residential area protected with its identity, cultural, social and historical moment values, integrity, spirit and with all its authenticity" ${ }^{\text {. }}$ Because it is close to the centre of the village and is one of the most important structures of Mustafapaşa, the structure that is the subject of this study has not lost its integrity.

Conservation includes the totality of the decisions that concern the past, present, and future of a cultural entity. In the conservation of an architectural monument, the history of the structure to be preserved, the on-site evaluations of the structure as well as written and verbal sources about the structure are used. Accordingly the ICOMOS Traditional Architectural Heritage Regulation of 1999 serves as an important guideline for the scientific studies $^{3}$.

The "Framework Convention on the Value of Cultural Heritage for the Society" (Faro Convention) adopted by the Council of Europe in

2 http://whc.unesco.org/en/list/357

3 http://www.icomos.org.tr/Dosyalar/ ICOMOSTR_0280118001353669454.pdf 


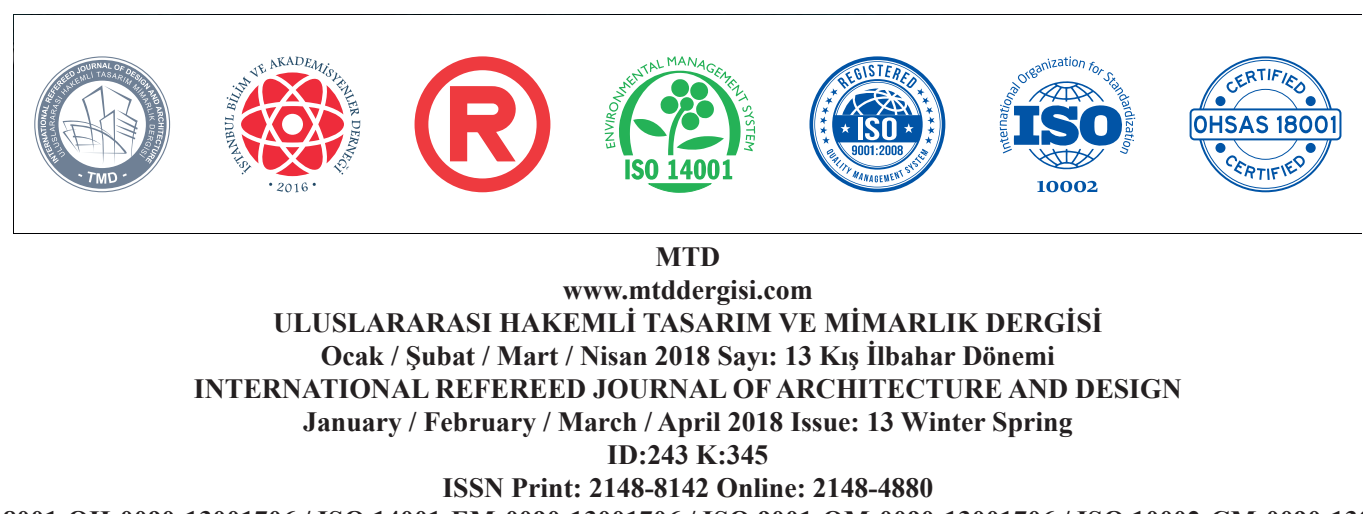

(ISO 18001-OH-0090-13001706 / ISO 14001-EM-0090-13001706 / ISO 9001-QM-0090-13001706 / ISO 10002-CM-0090-13001706)

(Marka Patent No / Trademark)

$(2015 / 04018-2015 / G E / 17595)$

$2005^{4}$, and The Namur Declaration, adopted at the Council of Europe's Ministerial Council meeting in Namur, Belgium, in 2015 highlight the importance of holistic protection. Similarly, the ICOMOS Paris Declaration entitled "The Driving Force of Development: Cultural Heritage" and adopted on December 1, 2011, states "culture is the fourth component of sustainable development, in addition to the economy, society and the environment" (Güçhan, 2012) ${ }^{5}$.

\section{FINDINGS}

4 http://www.europanostra-tr.org/files/file/ Farokonvansiyonu.pdf

5 http://www. Ecco-eu.org/fileadmin/assets/ documents/echy2018/Namur-Declar_en.pdf.pdf
The structure that is the subject of the present study is an example of a civil architecture registered on private property located in section 42, and parcels 5005 and 5006 within a $1 / 1000$ scale conservation development plan of the Mustafapaşa Municipality. The building is located on sloping ground and is surrounded by roads with Beyazit Street to the north and Köprü Street to the west (Fig. 1).

Within the scope of the Mustafapaşa Conservation Development Plan, the areas with architectural and textual character remain within the protected areas (NKVKK archives) of the urban preservation area.

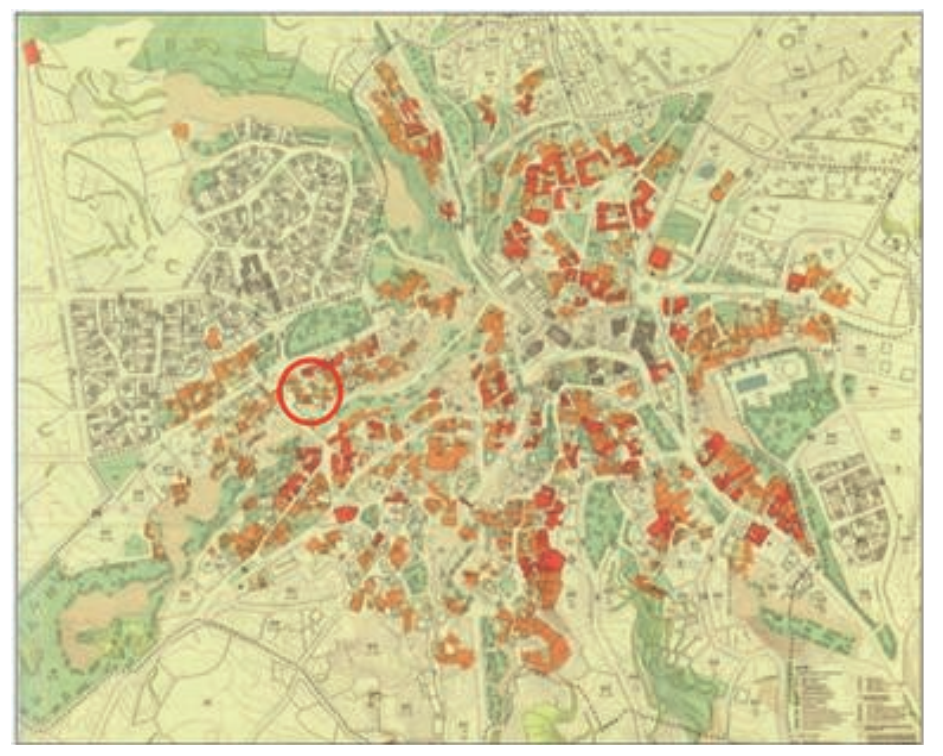

Figure 1. Studied Building in the Village of Mustafapaşa (Mustafapaşa Local Agenda 21 City Council, 2007: 69) 


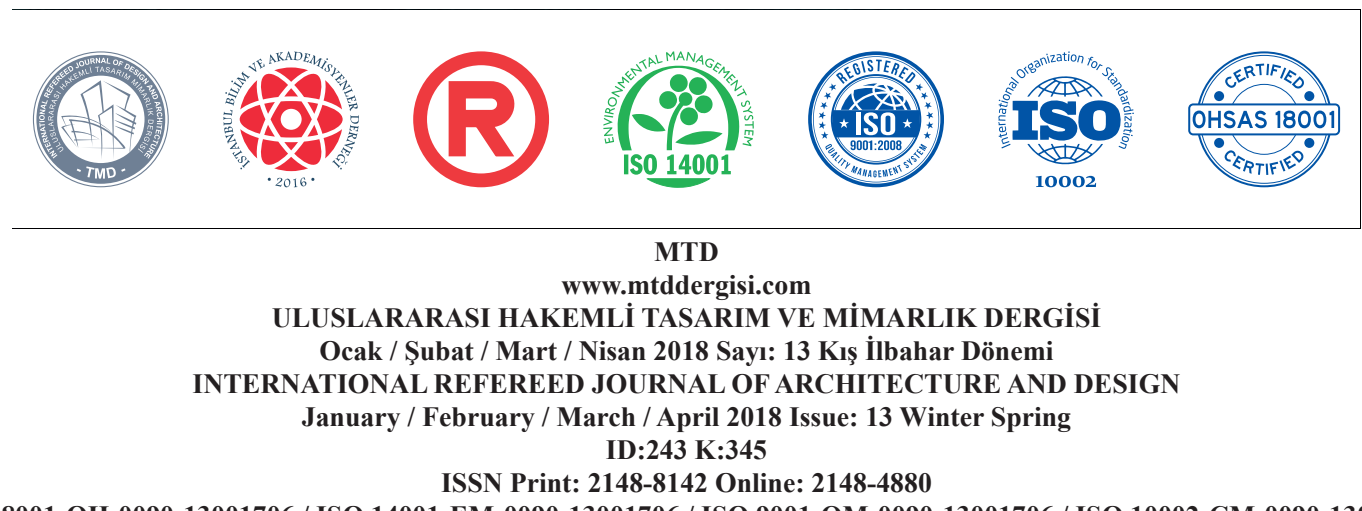

ISSN Print: 2148-8142 Online: 2148-4880
(ISO 18001-OH-0090-13001706 / ISO 14001-EM-0090-13001706 / ISO 9001-QM-0090-13001706 / ISO 10002-CM-0090-13001706)

(Marka Patent No / Trademark)

$(2015 / 04018-2015 / G E / 17595)$

The cut stone construction technique added to the facades of the carved rock structures has, over time, come to constitute the architec- tural character of the village of Mustafapaşa by accommodating harmonius colours and textures(Photos 1).

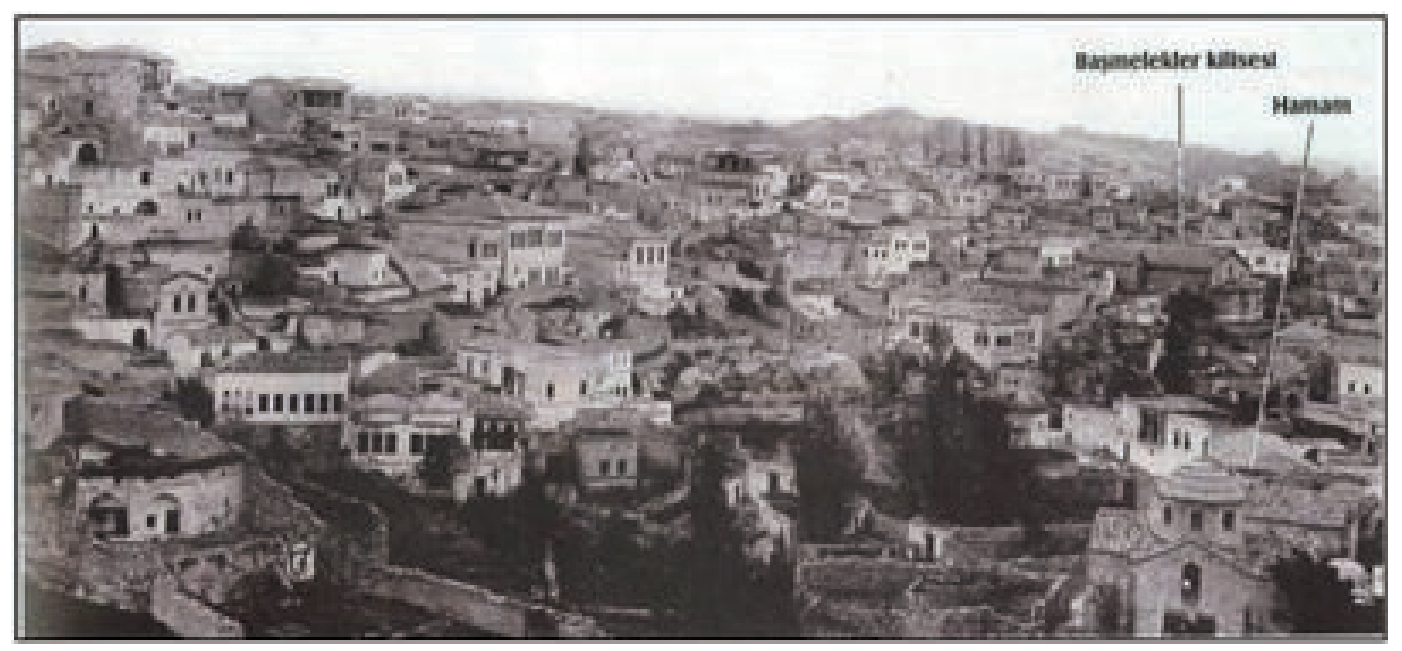

Photo 1. General View of Mustafapaşa (Mustafapaşa Local Agenda 21 City Council 2007:21).

Plan, facade, construction techniques and material properties of the structure

The structure consists of carved rock and cut stone masonry. It is located on two different levels of sloping ground with a lower courtyard and an upper courtyard and has three entrances (Fig.2). 


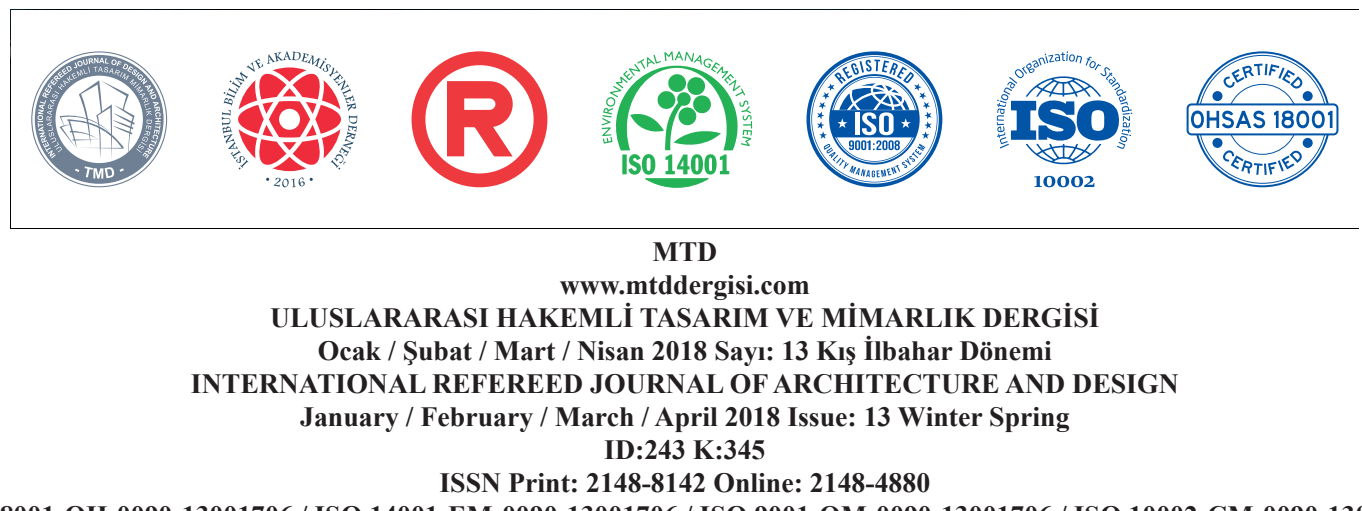

ISSN Print: 2148-8142 Online: 2148-4880
(ISO 18001-OH-0090-13001706 / ISO 14001-EM-0090-13001706 / ISO 9001-QM-0090-13001706 / ISO 10002-CM-0090-13001706)

(Marka Patent No / Trademark)

$(2015 / 04018-2015 / G E / 17595)$

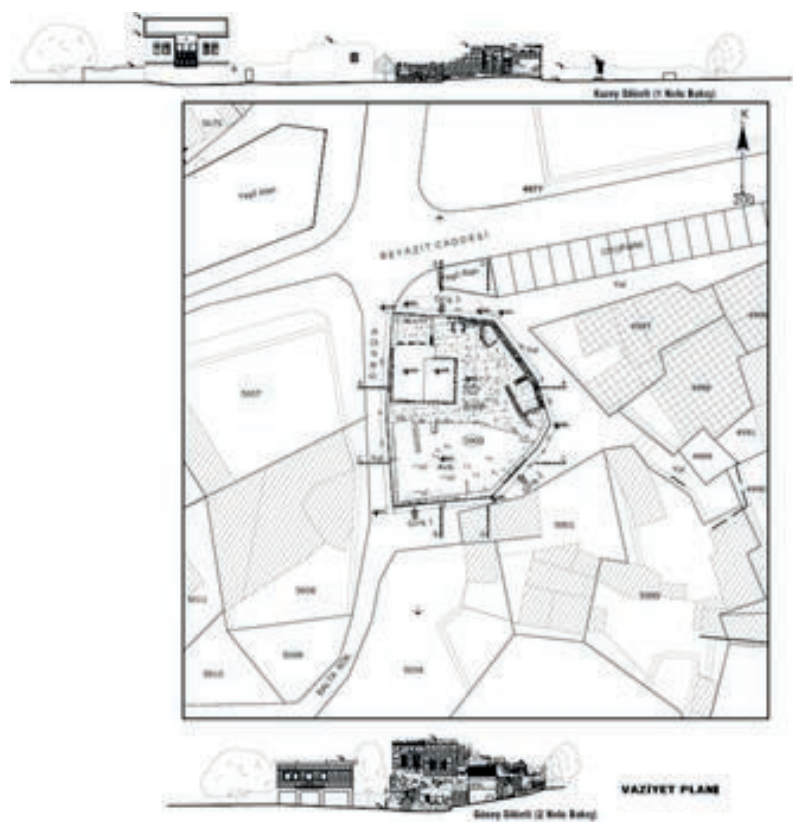

Figure 2. Layout Plan

There are rock rooms at elevations of -3.78 and -3.26 with cut stone spaces located at an elevation at 0.75 . The courtyard walls are constructed of a combination of cut stone and rubble stone. The lower courtyard which is at an elevation of -3.78 and is located on the southern front of the building is accessed through an arched door that has an inscription on it (Photo 2). The spaces at these elevations are formed by the carving of ignimbrite rocks, and the floors, ceilings and walls of the spaces are of volcanic ignimbrite.

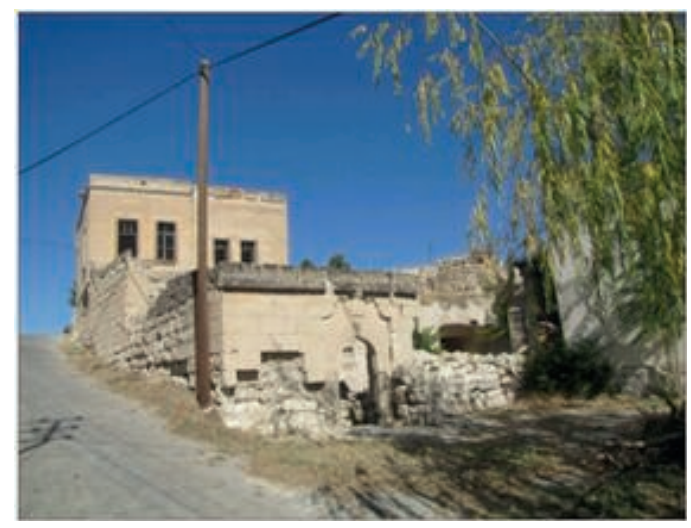

Photo 2. The View of the Building From the Bottom to the top 


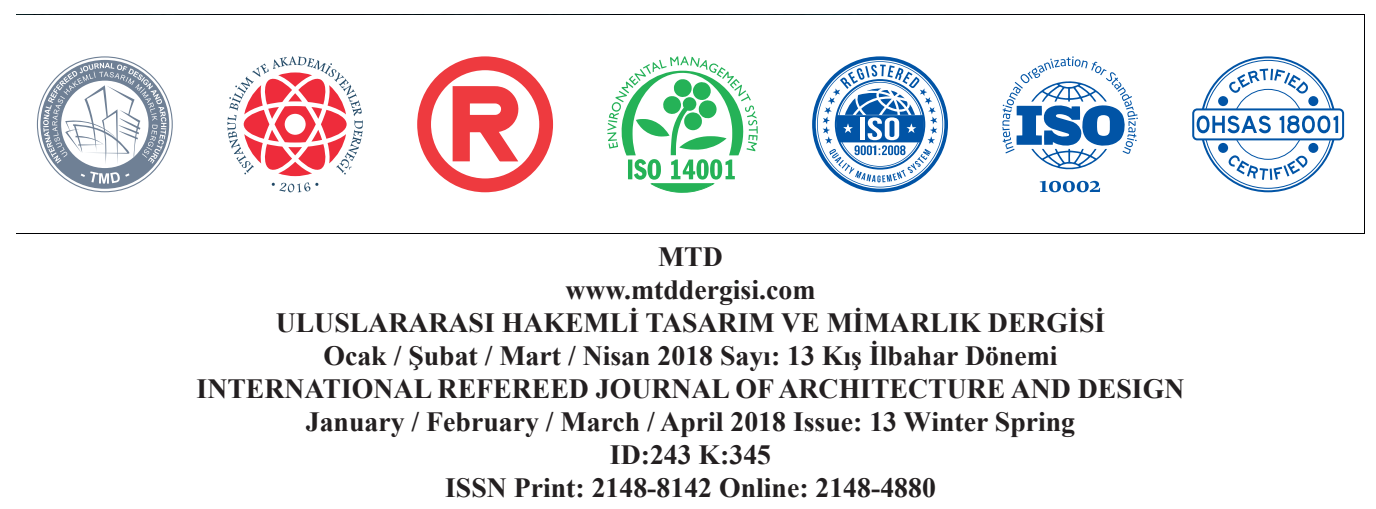

(ISO 18001-OH-0090-13001706 / ISO 14001-EM-0090-13001706 / ISO 9001-QM-0090-13001706 / ISO 10002-CM-0090-13001706)

(Marka Patent No / Trademark)

(2015/04018 - 2015/GE/17595)

On the southeast courtyard wall of the building, there are traces of a stone staircase that once, connected the upper and lower elevated courtyards. The southeast entrance that opened to a landing is now covered with stones.

\section{-3,78 Elevation Plan}

The date H.1235 M.1878 is inscribed under the script "Allah" (God) on the entrance of the arched door to the lower courtyard of the building (Photo 3). Considering the general architectural formation of Cappadocia, it is thought that the rock roofs in the lower courtyard were carved in 1878, and that structures of cut stone masonry were built on an as need basis date back to 1878 .

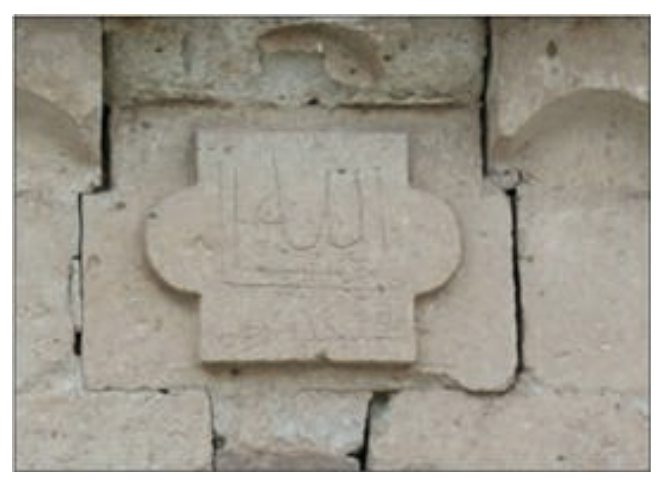

\section{Photo 3. The Date H.1235 M.1878 is Written Under the Script "Allah" (God) in the In- scription on the Entrance of the Lower Courtyard of the Building}

It is understood from the traces derived from the structure that there are porches with cut stone arches on the southern side of the ignimbrite rock rooms at the -3.78 elevation. On the southern edge of the lower elevation, there is a stone room numbered Z01 located on the northwest corner of the lower elevated cottage adjacent to the structure that is made of cut stone. The ceiling and walls of this stone room are partly destroyed (Fig.3). 


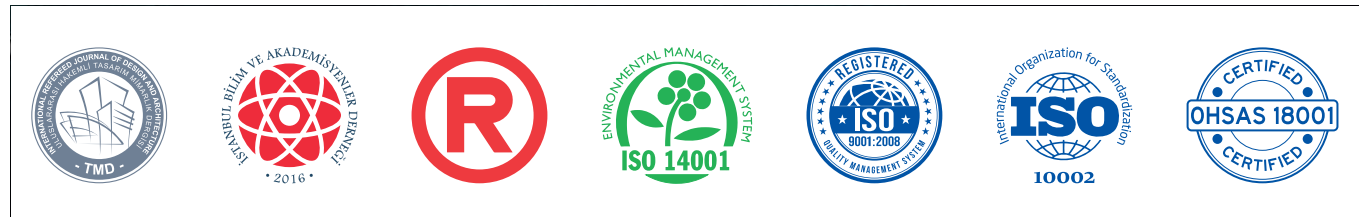

MTD

www.mtddergisi.com

ULUSLARARASI HAKEMLİ TASARIM VE MIMARLIK DERGISİ

Ocak / Şubat / Mart / Nisan 2018 Sayı: 13 Kış İlbahar Dönemi

INTERNATIONAL REFEREED JOURNAL OF ARCHITECTURE AND DESIGN

January / February / March / April 2018 Issue: 13 Winter Spring ID:243 K:345

ISSN Print: 2148-8142 Online: 2148-4880

(ISO 18001-OH-0090-13001706 / ISO 14001-EM-0090-13001706 / ISO 9001-QM-0090-13001706 / ISO 10002-CM-0090-13001706)

(Marka Patent No / Trademark)

$(2015 / 04018-2015 / G E / 17595)$

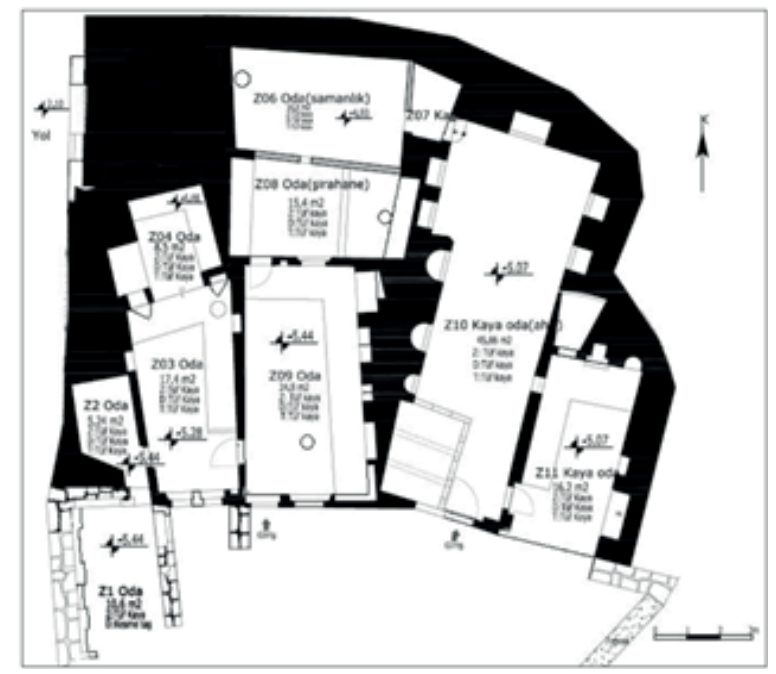

Figure 3. The Plan of the -3.78 Levation

On the western wall of the room, there is a window with a fireplace and a niche, and on the northern wall, there is an arch and the window of room Z02. On the eastern wall, there is an entryway and a niche. It is concluded that the room Z01 was later added as vaulted summer kitchen (Fig.4), (Photo 4).

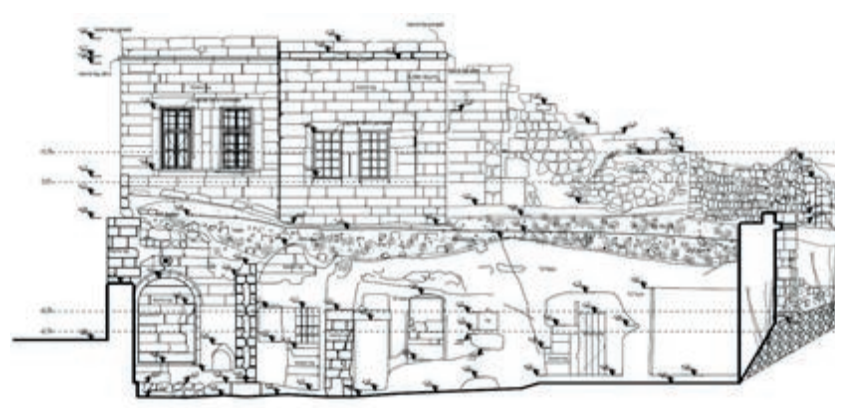

Figure 4. Section C-C 


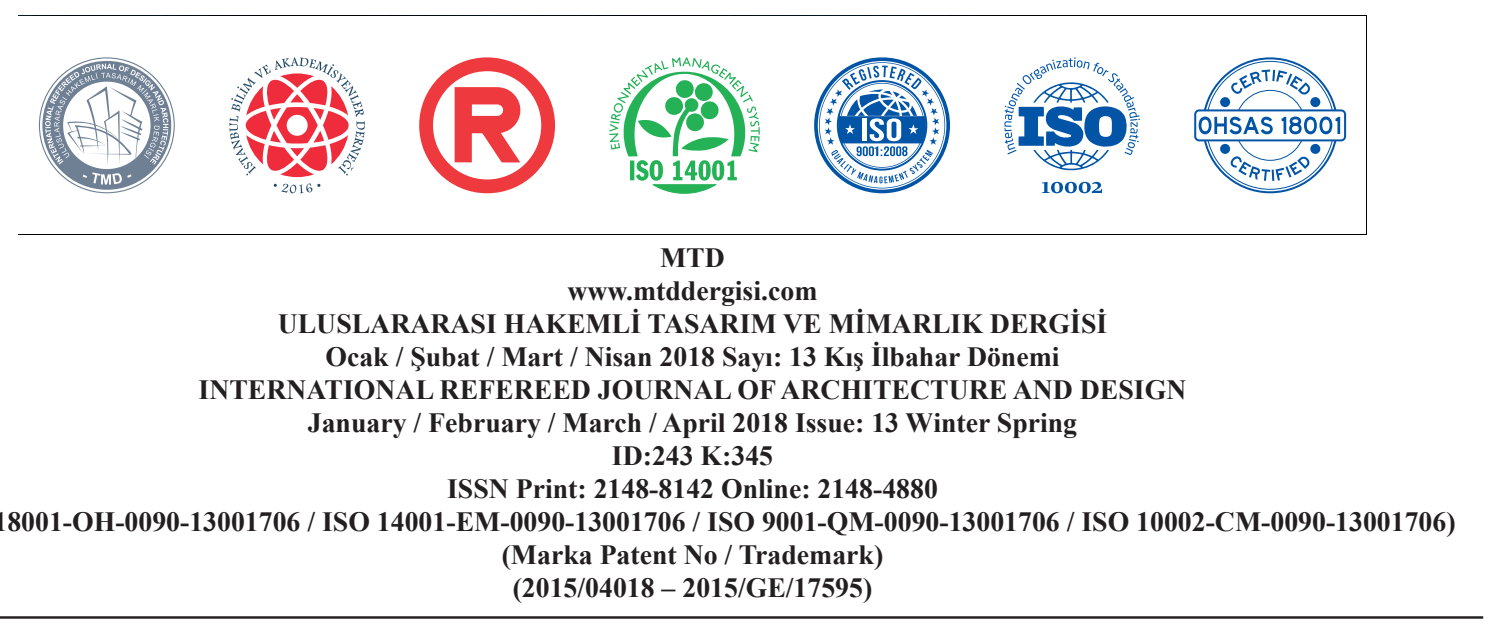

(ISO 18001-OH-0090-13001706 / ISO 14001-EM-0090-13001706 / ISO 9001-QM-0090-13001706 / ISO 10002-CM-0090-13001706)

(Marka Patent No / Trademark)

(2015/04018 - 2015/GE/17595)

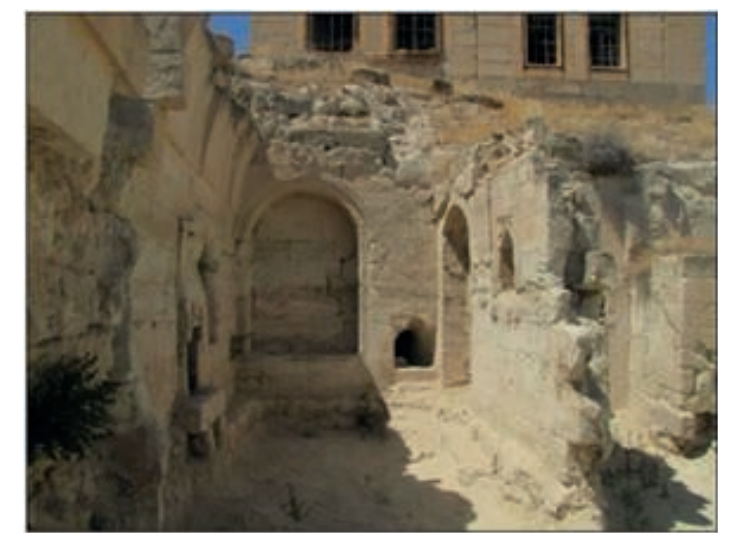

Photo 4. Room Z01

Room Z02 which is $2.20 \times 1.80 \mathrm{~m}$. in dimension and $1.78 \mathrm{~m}$ high, is located to the west of the room Z03, and it has a window opening to room Z01. The walls of this room, i.e., Z02, the floor covering and the ceiling are made of ignimbrite rock. There is a $63 / 170 \mathrm{~cm}$. door space that opens to room Z03.

Entry to room Z03 is accessed through room $Z 09$. The entrance door of the room is on the east wall and is illuminated by two rectangular shaped windows on the southern wall. There is one niche on each of the east and west walls and, two niches on the north wall.
Additionally, there is a passage way between these two niches on the north wall that provides access to the room $\mathrm{Z} 04$. The northern and eastern walls of Z03 are surrounded by an $18 \mathrm{~cm}$ high terrace constructed of ignimbrite rocks on the northeast corner of the room's terrace is a tandoori. The dimensions of room Z03 are $6.43 \times 2.50 \mathrm{~m}$ and it is $2.42 \mathrm{~m}$ high. The walls, floor covering and ceiling of the room are made of ignimbrite rock. However, the ceiling of the room has a unique cavity carved into an ignimbrite rock and the niches on the eastern and western walls are surrounded by wooden mouldings (Photo 5). 


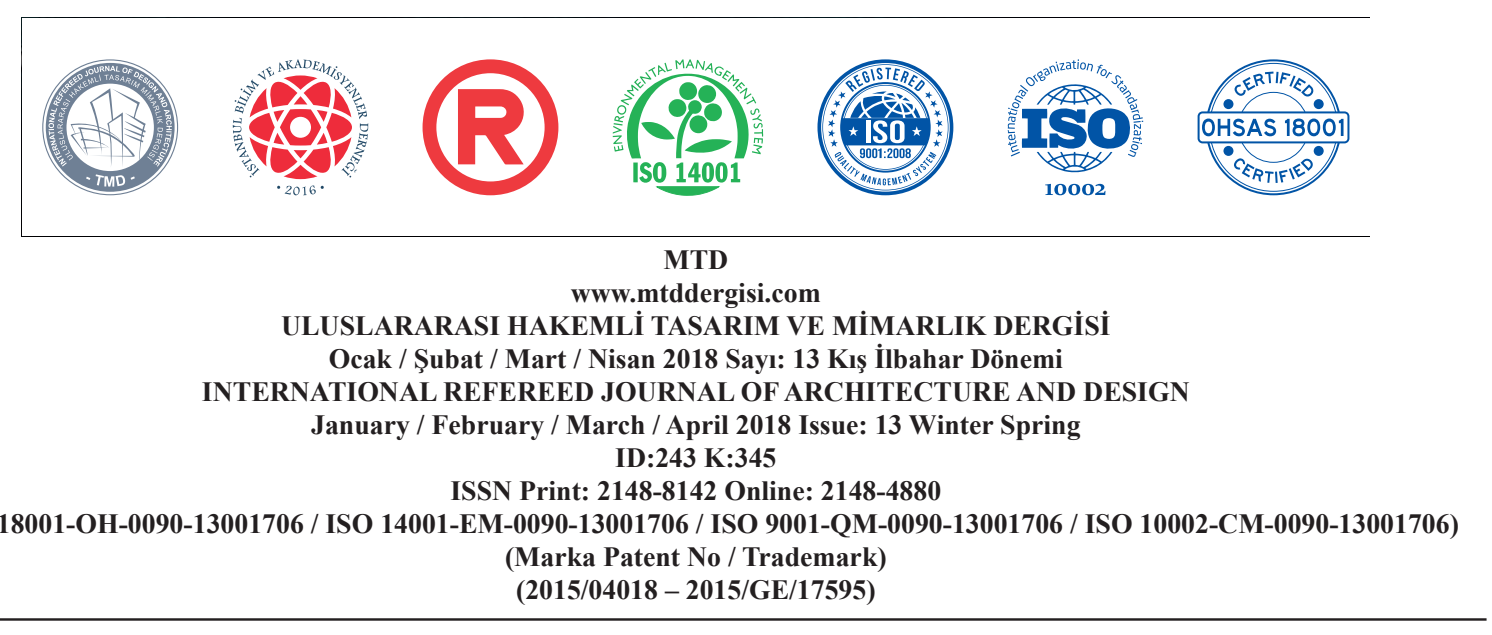

(ISO 18001-OH-0090-13001706 / ISO 14001-EM-0090-13001706 / ISO 9001-QM-0090-13001706 / ISO 10002-CM-0090-13001706)

$(2015 / 04018-2015 / G E / 17595)$

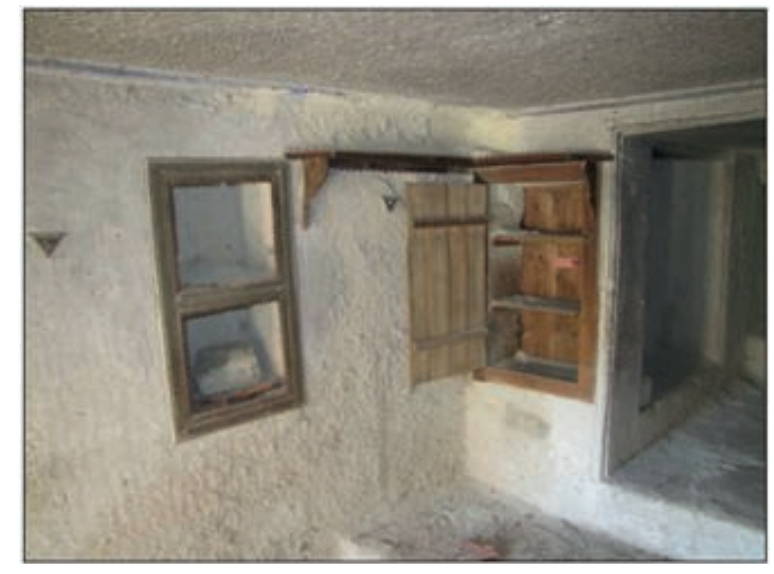

\section{Photo 5. Niches on the Eastern and Western Walls in Z03 Room}

Room Z04, which is reached by passing through the room Z03 is located north of room Z03. The walls, floor covering and ceiling of room Z04 are made of ignimbrite rock and its dimensions are $3.38 \times 1.97$ m width a height of $2.42 \mathrm{~m}$. On the western wall of the room, there is a niche measuring $1.00 \times 1.50 \mathrm{~m}$ and on the eastern wall, there is a $36 \mathrm{~cm}$ tall bench (Fig.5).

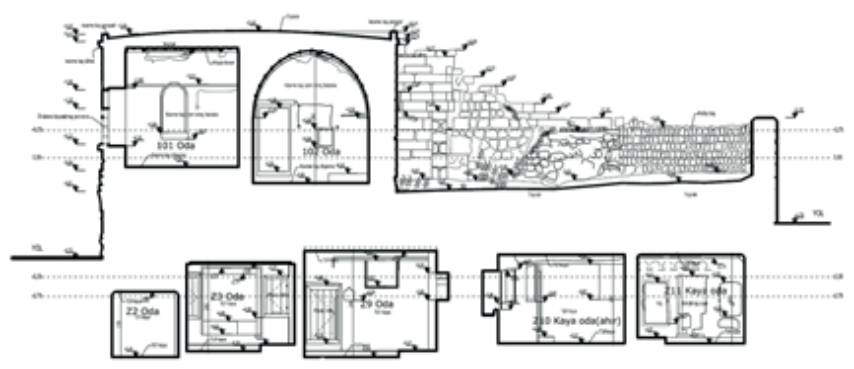

Figure 5. Section A-A

Room Z06 is located north of the rocky rooms. The ignimbrite entering from room $\mathrm{Z} 07$ is a carved rock room. The southern wall of the oven is made of cut stone, and there is a rectangular window that was used as a hayloft. The southern wall which was made of cut stone, was built to separate the grape juice room from the hayloft. The dimensions of room Z06 are $5.13 \times 3.30 \mathrm{~m}$, and $2.58 \mathrm{~m}$ height. The walls of the room, the floor covering and the ceiling are made of ignimbrite rock and there is a ventilation pipe in the ceiling. 


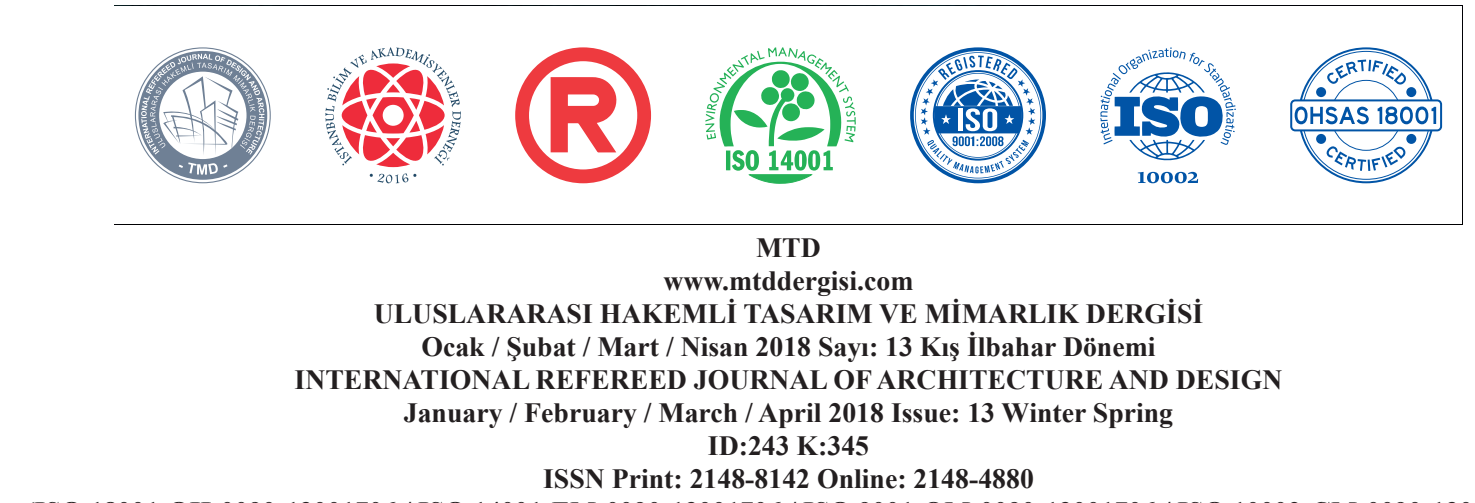

(ISO 18001-OH-0090-13001706 / ISO 14001-EM-0090-13001706 / ISO 9001-QM-0090-13001706 / ISO 10002-CM-0090-13001706)

(Marka Patent No / Trademark)

(2015/04018 - 2015/GE/17595)

Comprised of ignimbrite rock and containing no architectural elements room Z07 is a transition space between room Z06, i.e., the hayloft and room Z10, i.e., the barn. Room Z07 is separated from room Z06 by a wall made of cut stone. Room Z07 measures 1.88x1.64 $\mathrm{m}$ and is $2.58 \mathrm{~m}$ in height. The walls of the room, the floor covering and the ceiling are made of ignimbrite rock, and it is possible to access room Z07 from the room Z10, i.e., the barn through a two-step ignimbrite rock staircase.

Room Z08 was used as a grape juice room and is entered throgh a rectangular door from room Z09. All the walls, except the north wall, are composed of ignimbrite rock. There is a carved rock shelf on the west wall and a basin (grape juice) carved out of rock on the east wall (Photo 6). A cut stone opening measuring $37 \times 60 \mathrm{~cm}$ in the north wall provides accesss to room Z06 and the window, which measures $79 \times 70 \mathrm{~cm}$ on the south wall opens to room Z09. A wooden door in the southern wall that measures $69 \times 138 \mathrm{~cm}$ allows passage to room Z09 from the room Z08. Room $\mathrm{Z} 08$ measures $5.40 \times 2.49 \mathrm{~m}$ and is $2.37 \mathrm{~m}$ in height. The walls of the room, the floor covering and the ceiling are made of ignimbrite rock, and there is a ventilation pipe in the ceiling.

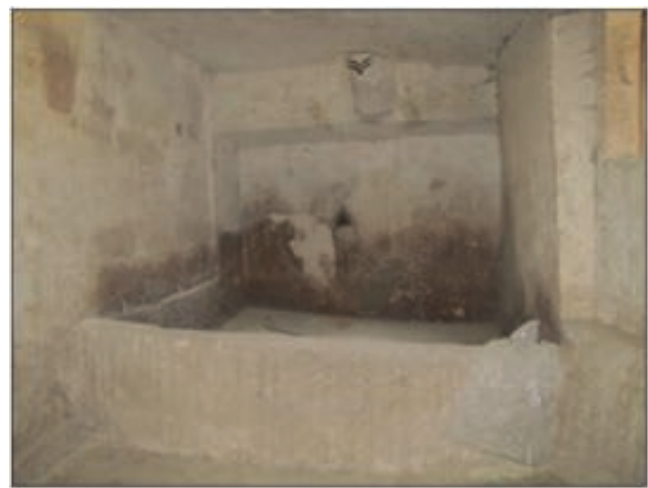

\section{Photo 6. The Sasin (Grape Juice) Carved Out of Rock on the Eastern wall}

Room Z09 was carved from ignimbrite rock. This room is accessed through a rectangular shaped door. The only window facing the courtyard was subsequently covered with cut stone. There are four niches on the eastern wall. These niches, except for those in the north, were covered with arches on top of the other niches. Room Z09 has a $17 \mathrm{~cm}$ high ignimbrite rock terrace surrounding the eastern and northern walls, and the room is connected to room Z08 with a door and window on the northern wall of the room. Room Z09 measures $4.18 \times 7.17 \mathrm{~m}$ and is $2.90 \mathrm{~m}$ in height. The walls of the room, the floor covering and 


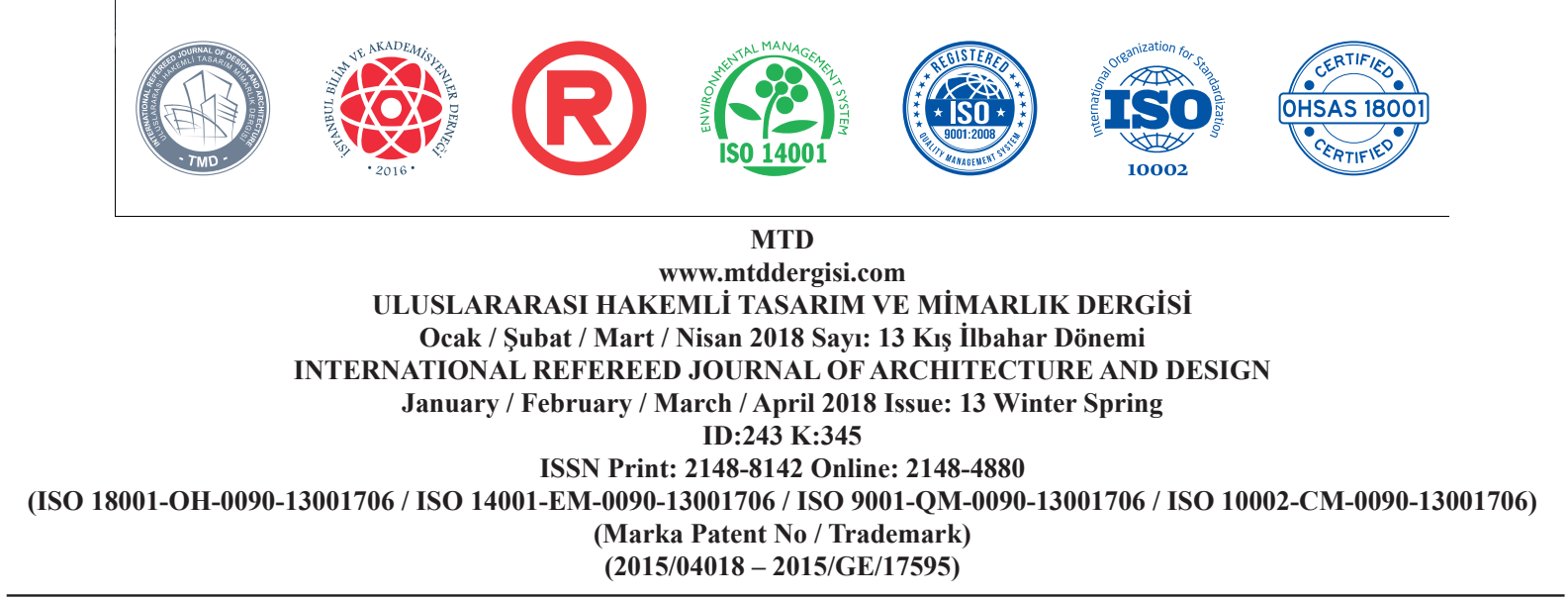

the ceiling are made of ignimbrite rock, and there is a ventilation pipe in the ceiling.

Room Z10 was carved from ignimbrite rock. There are niches of different dimensions and depths in all the walls of this room. The door on the north-west side of the room allows passage into room Z07. There is a poultry house made of stone to the west of the entrance. The niches of different sizes and depths in room $\mathrm{Z10}$, which is believed to have been a barn, were used as feedboxes for animals. Room Z11 was accessed through a wooden door which was thought to have been created later. Room Z10 measures 11.35x3.82 m. and is $2.43 \mathrm{~m}$. in height. The walls of the room, the floor covering and the ceiling are made of ignimbrite rock.
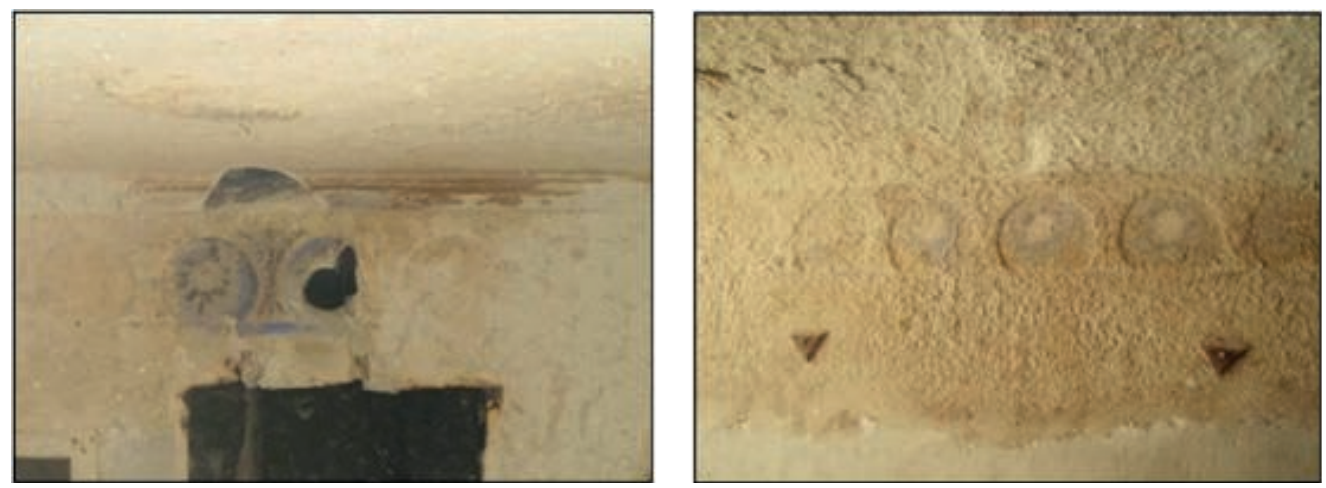

Photos 7, 8. The Ornamentations on the North Wall of Room Z11

\section{-3.26 Elevation Plan}

At this lower elevation, i.e., -3.26 , the full capacity of the courtyard and the additional warehouse numbered Z05 are available.
The entrance to room Z11 has been destroyed. There is a fireplace that was demolished on the north wall. There is a small niche to the east and a larger niche to the west of the fireplace. There is a window on the western wall that connects to room Z10 and a door on the western wall that allows passage into this room. There is a $16 \mathrm{~cm}$ high ignimbrite rock terrace that extends along the northern and western walls. Room Z11 measures 5.73x2.88 m. and is $2.43 \mathrm{~m}$ in height. The walls of the room, the floor covering and the ceiling are made of ignimbrite rock. In addition, there are ornamentations made with ocher on the ignimbrite rock walls (Photos 7, 8).
Room Z05, i.e., the -warehouse- is located on the north side of the rock rooms. The entry to the room Z05 is accessed by a path in the western part of the demolished building. The rock room is covered with a barrel vault that 


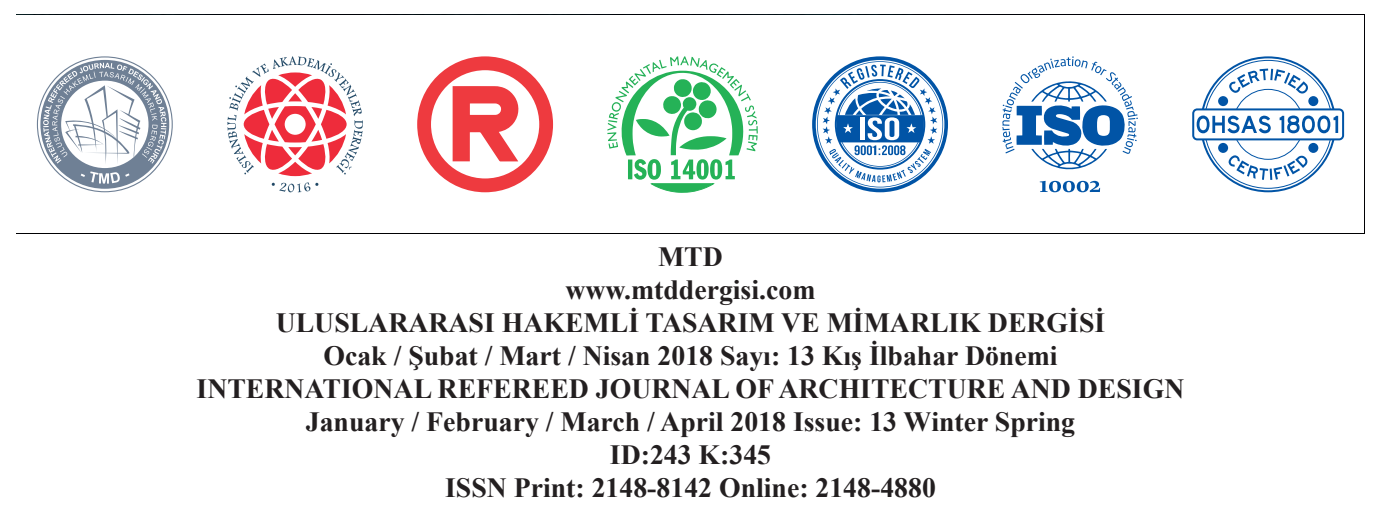

(ISO 18001-OH-0090-13001706 / ISO 14001-EM-0090-13001706 / ISO 9001-QM-0090-13001706 / ISO 10002-CM-0090-13001706)

(Marka Patent No / Trademark)

(2015/04018 - 2015/GE/17595)

is supported by three arches exhibiting a flat shape. There is a large niche on the north side and three niches on the south side of the room and it is located at the upper courtyard compared to the rock roofs, which were located at the lower courtyard. Room Z05 measures $4.80 \times 2.43 \mathrm{~m}$ and has a height of $2.28 \mathrm{~m}$. The walls of the room and the floor covering are composed of ignimbrite rock and the ceiling is made of cut stone.

\section{+0.75 Elevation Plan}

The upper courtyard at an elevation of +0.75 is accessed from the north facade. The entrance of the upper elevation courtyard and the walls have partially disappeared. The rooms $101,102,103,104$ and 105 in upper elevation courtyard are at this elevation (Fig.6).

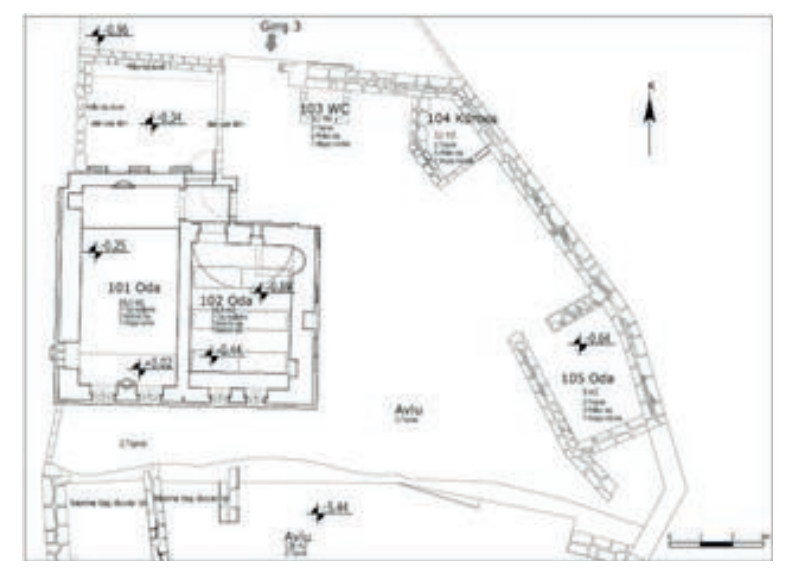

Figure 6. Upper elevation (+0.75) courtyard plan şeması

The rooms at this elevation were built using a cut stone masonry construction technique. Rubble stones were used in the areas that once functioned as poultry houses in the courtyard, warehouse and toilet. Rooms 101 and 102 located at the upper elevation, had areas measuring $19.5 \mathrm{~m}^{2}$ and $14.5 \mathrm{~m}^{2}$, respectively. At the west side of the entrance to the upper courtyard, there is a room with a collapsed arch. Given the general situation of the structure, it was observed that while the ignimbrite rock areas in the lower courtyard were preserved, all of the rubble stone-walled areas were destroyed and the rooms constructed of cut stone with arched and wooden ceilings were partially or totally destroyed (Fig.7). 


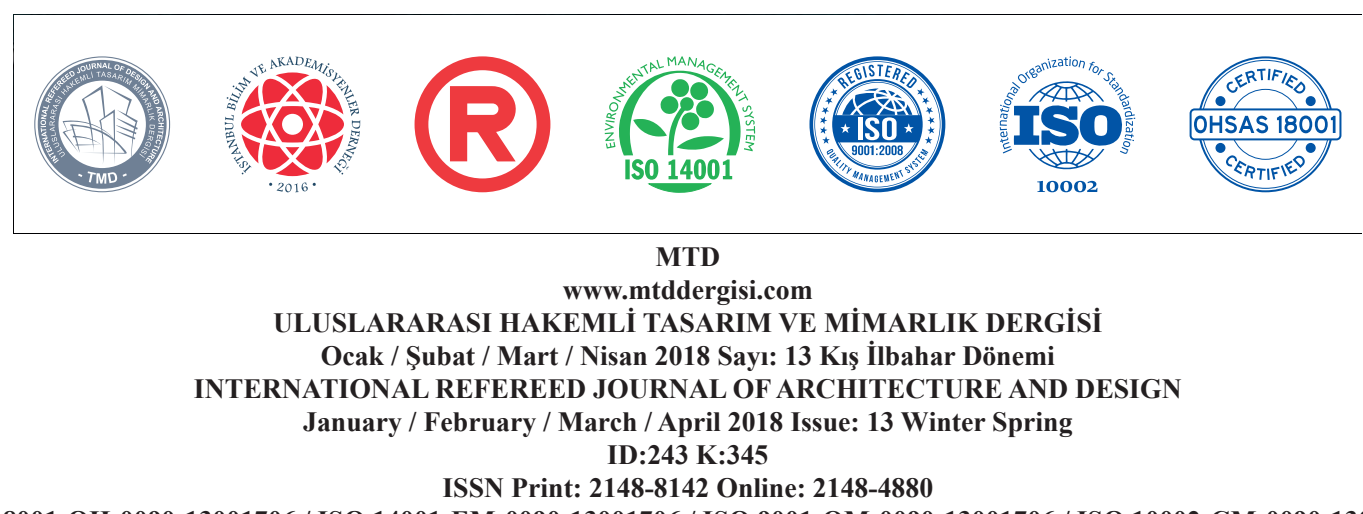

ISSN Print: 2148-8142 Online: 2148-4880
(ISO 18001-OH-0090-13001706 / ISO 14001-EM-0090-13001706 / ISO 9001-QM-0090-13001706 / ISO 10002-CM-0090-13001706)

(Marka Patent No / Trademark)

$(2015 / 04018-2015 / G E / 17595)$

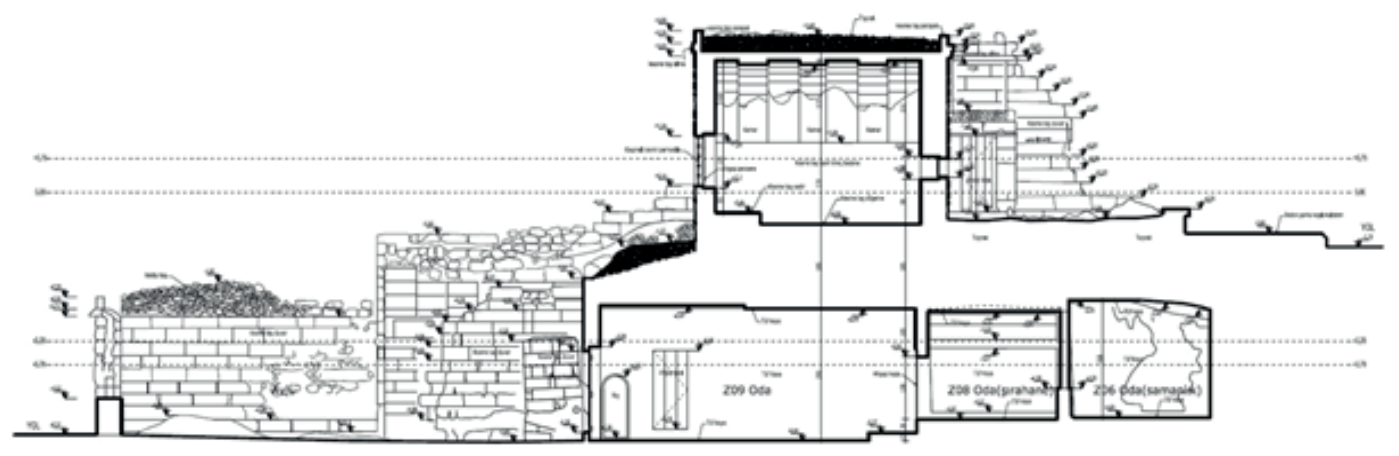

Figure 7. Section B-B

Room 101 is located on the west side of the rooms in the upper courtyard. Room 101 measures $3.11 \times 6.25 \mathrm{~m}$ and is $3.25 \mathrm{~m}$ high. The walls of the room were constructed of cut stone. The entrance gate is located on the north end of the east wall, and the room is illuminated through a rectangular window with two wooden wings on the south side (Photo 9). In front of the windows on the south facade, there is a $27 \mathrm{~cm}$ tall seki made of cut stone on the ground. The floor of the room 101 has stone flooring and wooded lath. There is a window on the west wall that has been closed by bonding. At the north end of the west wall, there is a niche that has, a skylight window and there is also a circular planned niche on the north wall.

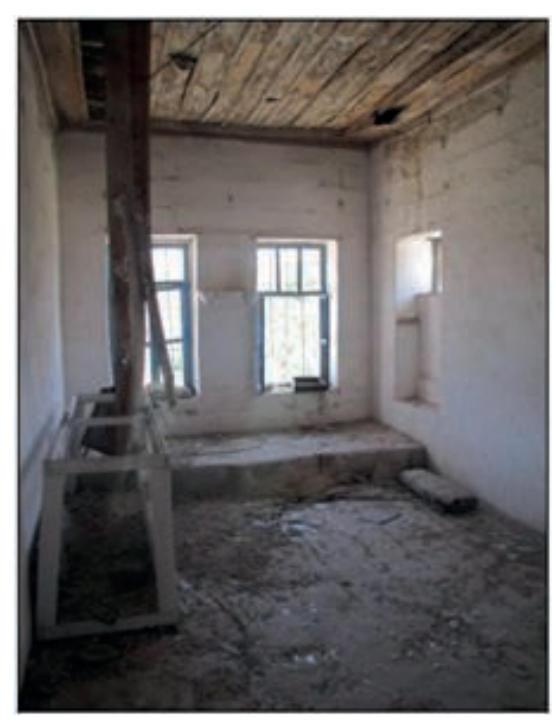

Photo 9. The South Wall of Room 101 and the seki 


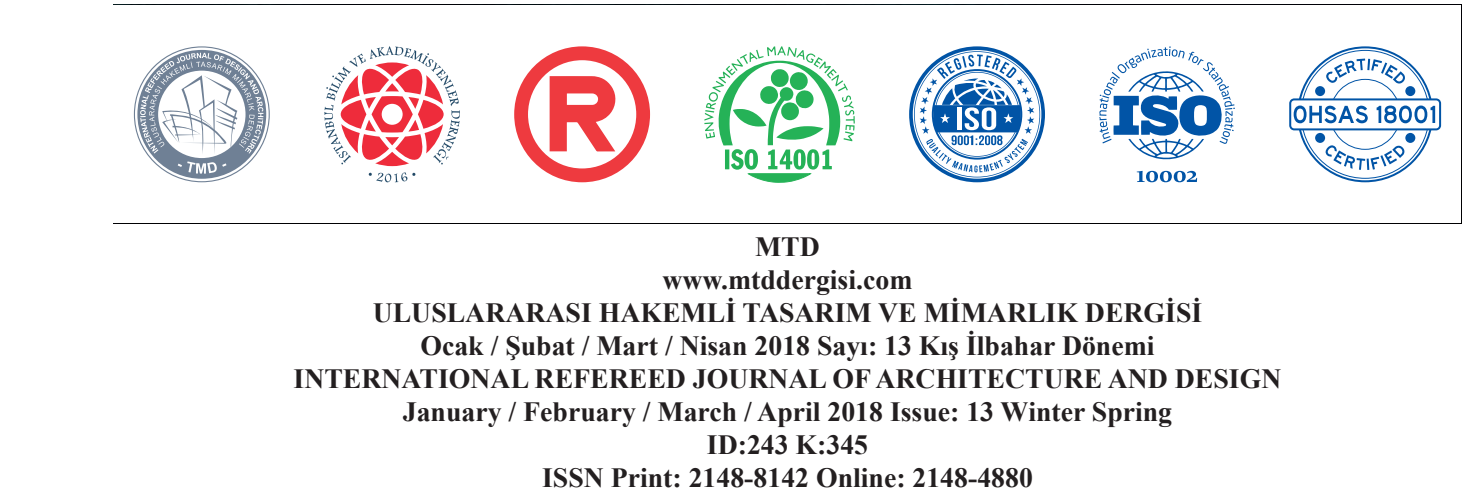

(ISO 18001-OH-0090-13001706 / ISO 14001-EM-0090-13001706 / ISO 9001-QM-0090-13001706 / ISO 10002-CM-0090-13001706)

(Marka Patent No / Trademark)

(2015/04018 - 2015/GE/17595)

Room 102 is made of cut stone and is located on the east side of the rooms on the upper elevation. The room is covered by a cradle vault extending along the north-south axis and supported by three arches. On the north wall of the entrance door, there is a small window to the east of the door, and the room is illuminated by two rectangular windows on the south wall (Photo 10).

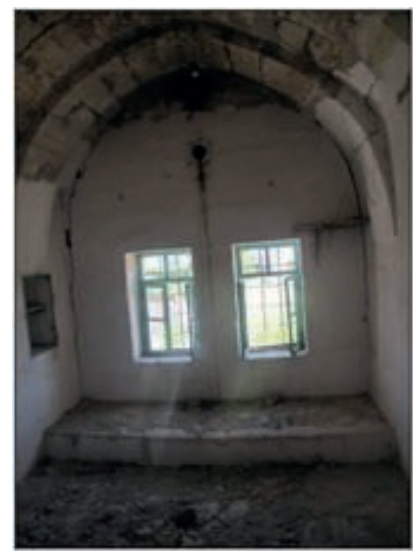

Photo 10. The North Wall of Room 102

On the east wall, there are two niches, one of which is circular and the other rectangular. There is a concrete basin, which was built later, used for washing that sits in front of the circularly planned niche. On the south wall, there is a $25 \mathrm{~cm}$ sofa made of stone similar to that room 101. The floor of the room is covered with stone. Room 103, which is a toilet room made of cut stone is located on the eastern edge of the upper courtyard entrance door. Unfortunately, this room was demolished.

Room 104, i.e., the -poultry house- was constructed of rubble stones on the northeast corner of the upper courtyard. The walls of the room have collapsed. Room 105, which is made of rubble stone but has no cover, is located on the eastern side of upper courtyard. The room is accessed through an entrance located on the north side.

There were two rectangular windows on the southern facades of cut stone rooms located at the upper elevation. These windows were fitted with interlocked iron bars. While the western wall of the room was finished with a profiled moulding, the wall of the room on the east side was finished with a plain and simple moulding (Fig. 8). 


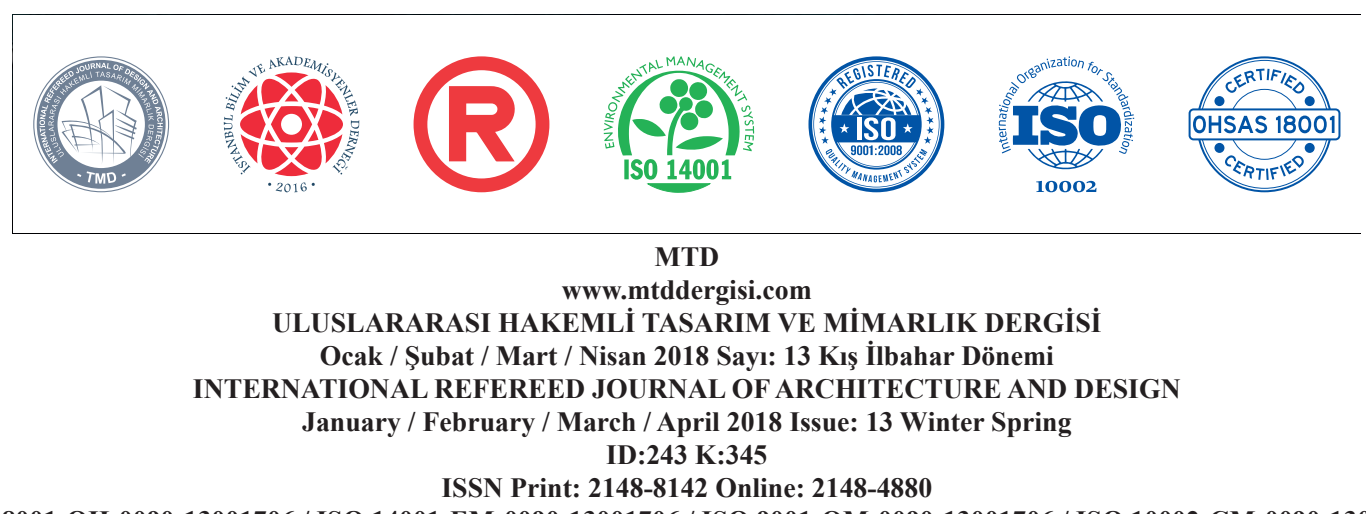

ISSN Print: 2148-8142 Online: 2148-4880
(ISO 18001-OH-0090-13001706 / ISO 14001-EM-0090-13001706 / ISO 9001-QM-0090-13001706 / ISO 10002-CM-0090-13001706)

(Marka Patent No / Trademark)

$(2015 / 04018-2015 / G E / 17595)$

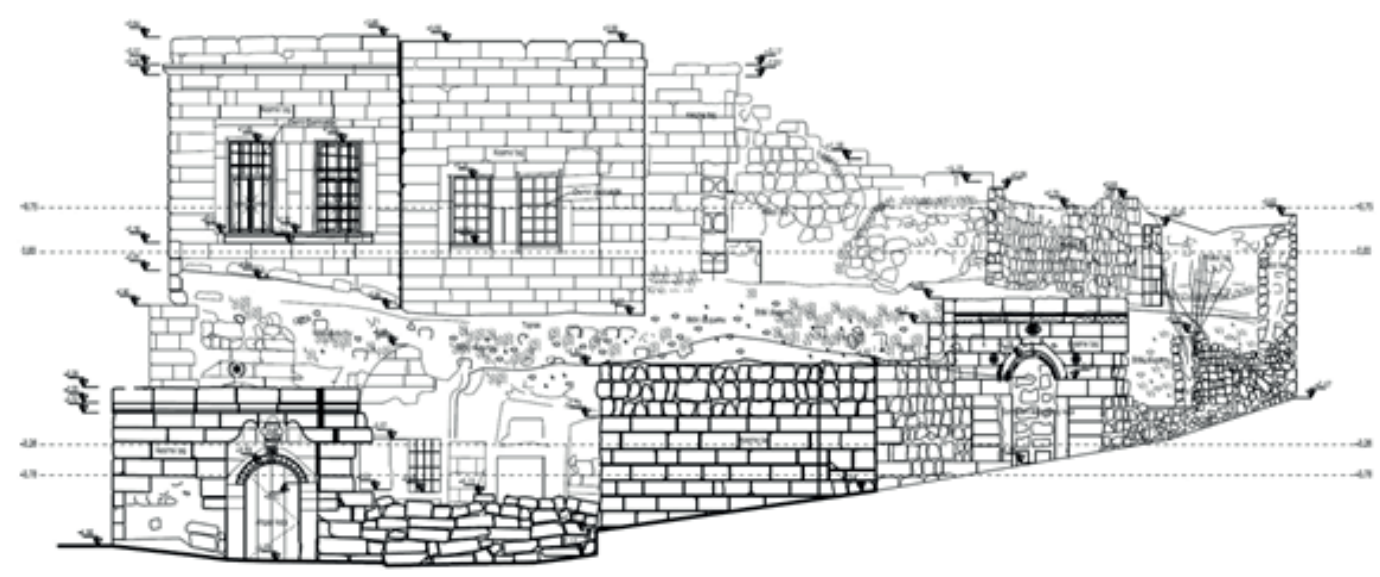

Figure 8. The south Facade of the Building

On the north side of the building, stones that most of it has collapsed. The courtyard wall on supported the arch are in ruins today. Although this facade is made entirely of cut stone (Photo part of the courtyard's entrance door is intact, 11).

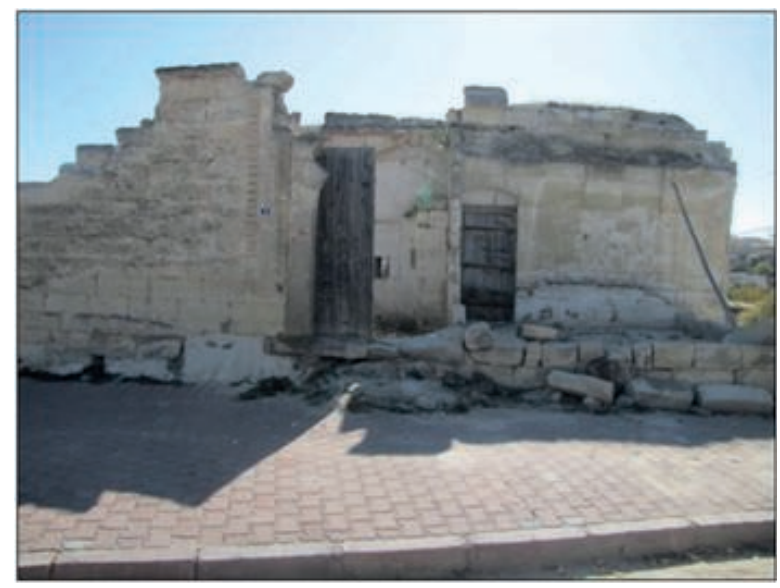

\section{Photo 11. Upper Elevation Courtyard and North Facade of the Building}

The wall of the upper elevation room located on the western facade of the building was made up of cut stone and finished with a cornice, and two rows of parapet stones were placed on top of it. There were two windows on the facade. A large rectangular window opening was later closed with stone from the inside of the room, and an elliptical shaped top window was located on the north portion of the west ceiling. There is a very simple gar- 


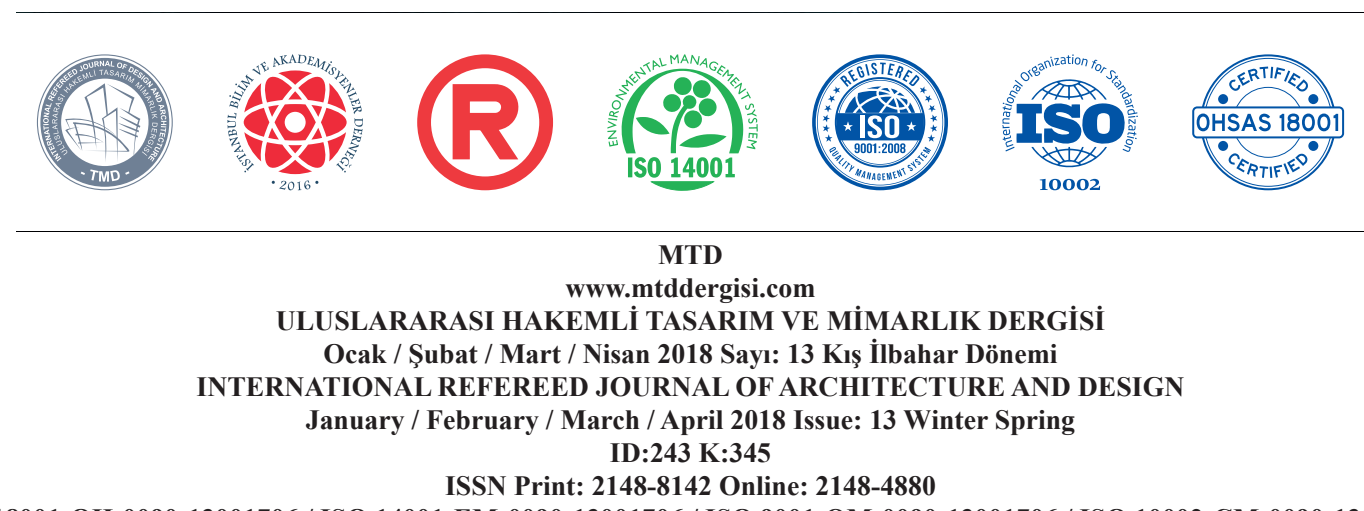

ISSN Print: 2148-8142 Online: 2148-4880
(ISO 18001-OH-0090-13001706 / ISO 14001-EM-0090-13001706 / ISO 9001-QM-0090-13001706 / ISO 10002-CM-0090-13001706)

(Marka Patent No / Trademark)

$(2015 / 04018-2015 / G E / 17595)$

goyle on the stone that catches one's attention. rows of stones are believed to have been the On the western front, stones that are arranged beginning of an arch (Photo 12).

in four rows between the rubble stones. These

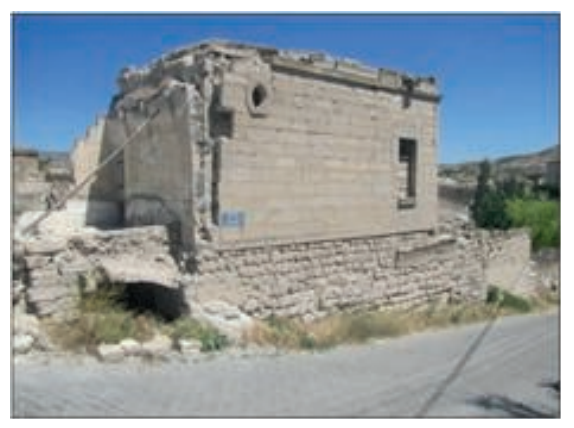

\section{Photo 12. West Facade of the Building}

The eastern facade of the courtyard wall on the eastern side of the building was covered with rubble stone. There is a round arched door made of cut stone located on the eastern facade of the courtyard wall. There are a total of three badges, one on the arch and one each on the east and the west facades. The entrance gate to the courtyard was closed at a later time. The traces of the staircase leadings to the upper courtyard from the lower courtyard of the building is visible on the eastern courtyard wall (Photo 13), and there are three joist hanger arch stones and a niche on the eastern front of the room 102 (Photo 14).

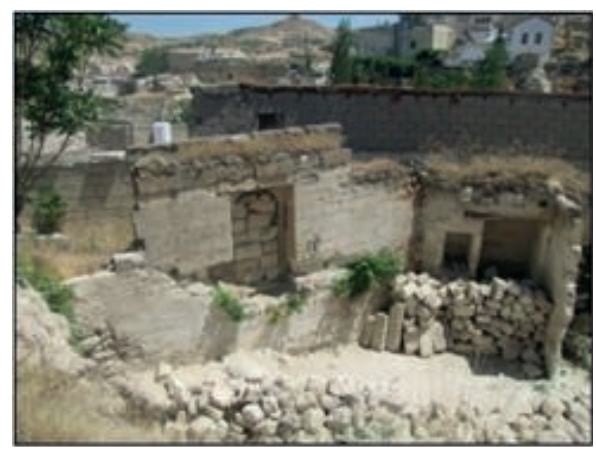

Photo 13. The View of the Building From the Upper Courtyard to the Lower Courtyard 

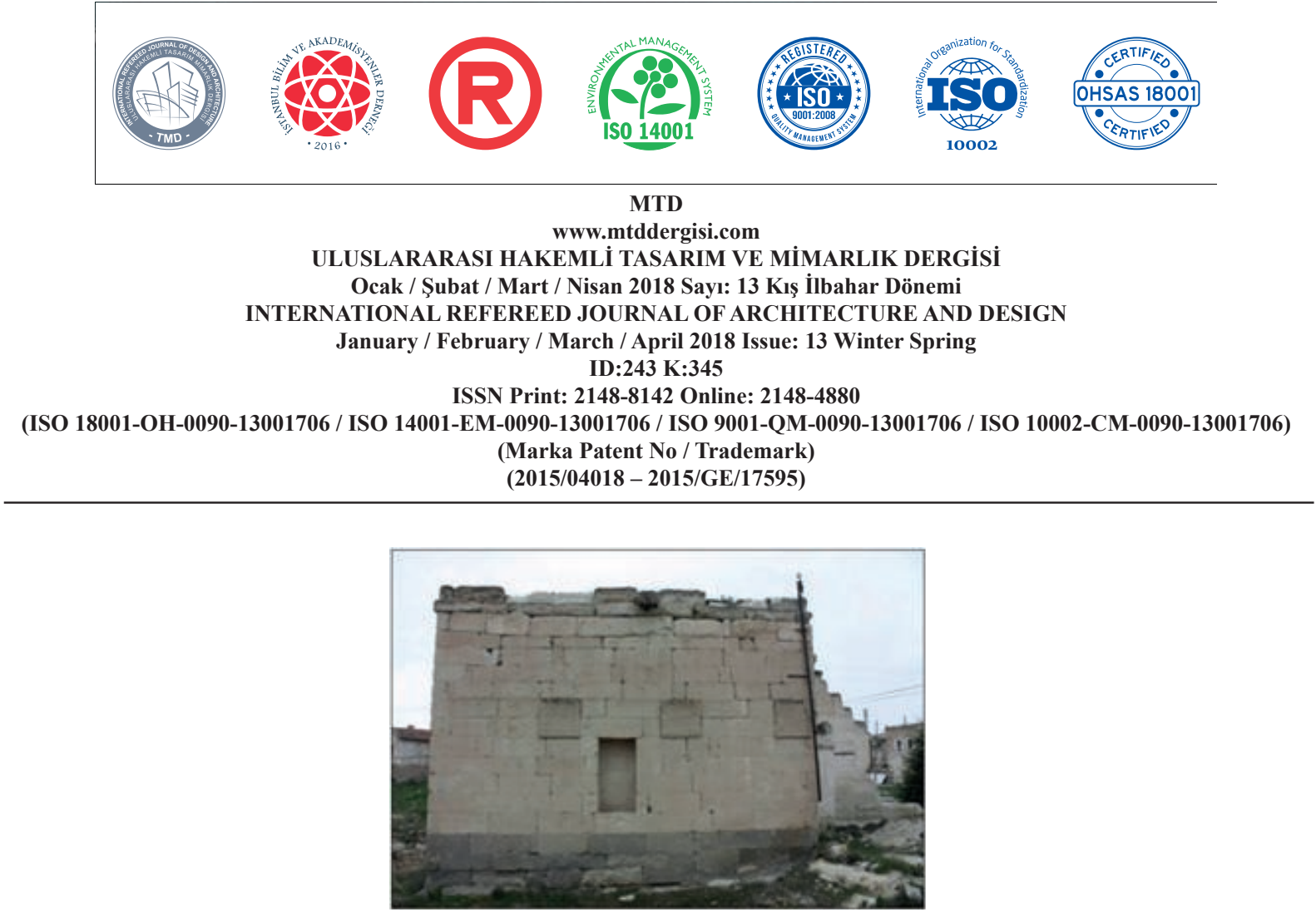

\section{Photo 14. The East Facade of the Building}

The upper elevation rooms were built using a cut stone masonry technique. Specifically, the gaps between two rows of cut stone arch filled with rubble stone, and mortar is used as a binding material. Two of the facades of the building were constructed made of cut stone, and the load bearing walls whose interior parts were made of mixed stone mud were ,on average, $70 \mathrm{~cm}$ thick. The tops of the load bearing walls in room 101were covered with wood lath ceilings. Room 102 was covered with vaults, but to prevent the vault from increasing the ceiling height, the supporting walls didn't exceed $180 \mathrm{~cm}$ in height. The roof of the rooms is a flat roof covered with soil.

\section{Deterioration in the Structure}

The building was subjected to many problems due to abondenment. For example, many components were partially or completely destroyed both in terms of space and architectural elements at both elevations. The room on the north side of the upper floor, the upper courtyard entrance and the spaces in the lower courtyard were demolished.

Because the building had not been used for many years major cracks and splits in the rock rooms carved out of ignimbrite rocks caused static problems such as cracks and vertical deviations in the upper rooms made of cut stone due to dampness and water problems originating from the top cover. The cracks on the southern wall of the room on the east side of the upper floor, the split in the dilatation of both rooms on the upper floor, and the cracking and splitting of the south entrance door of the courtyard were among the major problems. Many problems with the building were caused by the fact that the top covering did not provide the necessary insulation, which resulted in. The decay of the wooden ceiling of room 101 on the upper floor. Additionally, there was substantial dampness in the top of the vault of room 102, and the walls of the courtyard made of rubble stone exhibited joint 


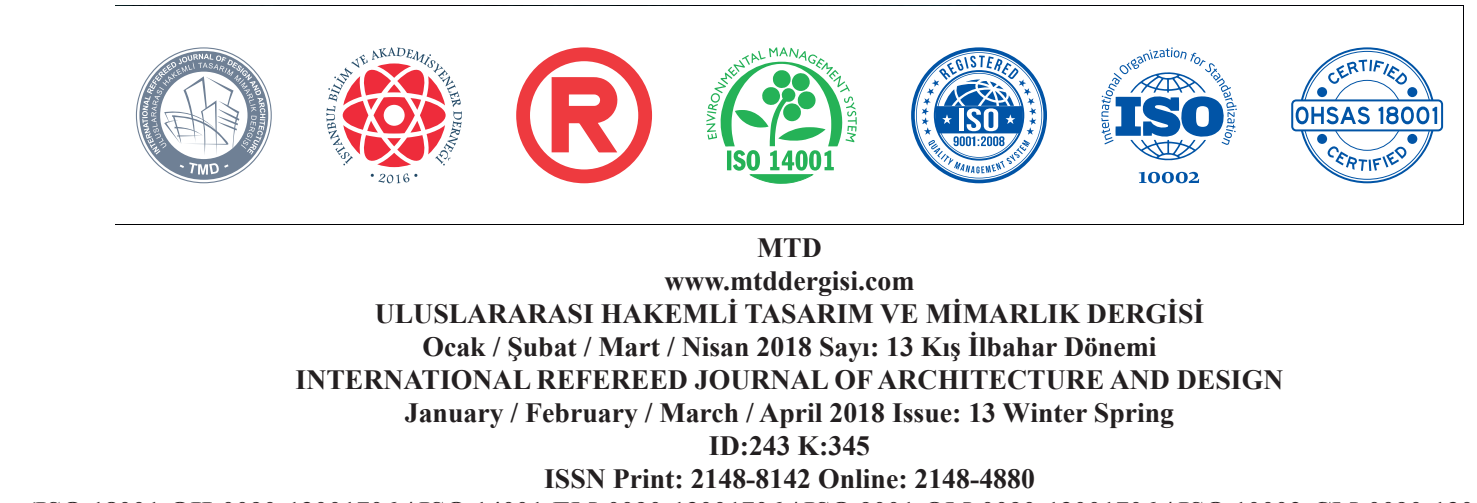

(ISO 18001-OH-0090-13001706 / ISO 14001-EM-0090-13001706 / ISO 9001-QM-0090-13001706 / ISO 10002-CM-0090-13001706)

(Marka Patent No / Trademark)

$(2015 / 04018-2015 / G E / 17595)$

discharges near the ground level. Near the soil elevation level, the water and dampness coming from the ground dissolved the joints and caused them to drain. In many parts of the structure, especially in the cut stone and rubble stone surfaces, there was a visible loss of components such as the deterioration of the cut stone and rubble stone surfaces making up the courtyard wall. The surfaces also displayed serious loss and deterioration.

\section{Restitution Problems in the Structure}

In the parcel where structures are located at two different elevations, there is no clear information about when the rock rooms at the lower elevation level were carved or when the carving was initiated. However, it is evident that the structures on the parcels were built at different times based on the relationships of the structures with each other and based on the construction techniques. The date inscribed above the entrance of the lower courtyard is H.1235 M.1878. According to this information, the rock rooms on the lower elevation and the walls of the lower elevation courtyard are the parts that were built first. The cut stone rooms located in the lower courtyard, the cut stone rooms located in the upper elevation and upper courtyard walls were built later.

Documents That Shed Light on the Restitution
During the survey, the plan of the structure and at the third dimension, especially the wall levels and the original architectural items belonging to beginning and ending points of arches and vaults were determined and buildings from similar periods were examined, and a restitution project was prepared in the light of the photographs, documents and information about the building obtained from the archives of the Nevşehir Cultural Assets Preservation Directorate, and information obtained from the property owner.

According to the registration sheet available on the board, the statement read as follows "The building consists of rock rooms located at the lower elevation and the rooms made of cut stone located at the upper elevation above them. Both elevations are surrounded by the courtyard wall, and the entrance gate of the courtyard wall at the upper elevation is destroyed. The lower courtyard entrance doors are in good condition. In addition, while there are no significant cracks and splits in the rock rooms carved from the ignimbrite rocks, it is understood that since the building was not used for a long time and due to dampness and water problem originating from the top cover, there are static problems such as cracks and splits, in the rooms made of cut stone. The inscription above the entrance to the lower elevation courtyard 


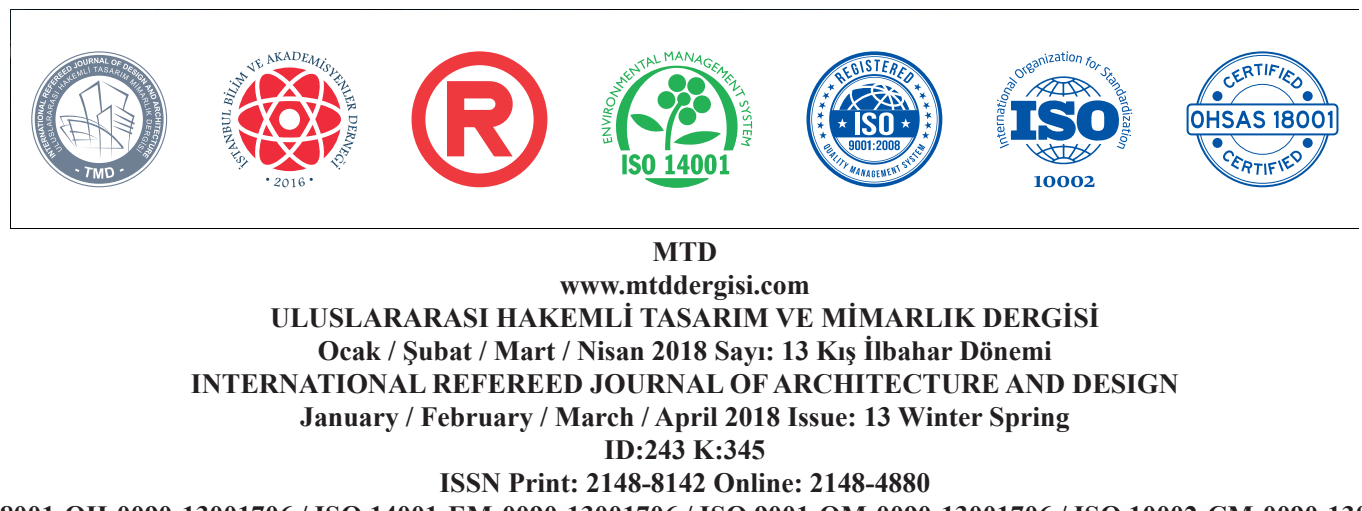

(ISO 18001-OH-0090-13001706 / ISO 14001-EM-0090-13001706 / ISO 9001-QM-0090-13001706 / ISO 10002-CM-0090-13001706)

(Marka Patent No / Trademark)

$(2015 / 04018-2015 / G E / 17595)$

indicates that the date of construction is $H$. 1235 M. $1878^{\prime \prime}$ is available ${ }^{6}$.

According to property documents of the building, the property registered in parcels 5005 and 5006 is privately owned. In the land register dated 6 July 2011, parcel 5005 par-

6 H. 1235 is M. 1878 (The translation about the date is done by the writers) . cels has a parcel surface area of $103 \mathrm{~m}^{2}$ and a masonry house with a courtyard.

In the land register dated 12 May 2011, parcel 5006 is $275 \mathrm{~m}^{2}$ and has a masonry house. On the cadastral map sheet, the boundaries of the building are located in parcels 5005 and 5006 , and the blocks of the building are identified (Fig. 9).

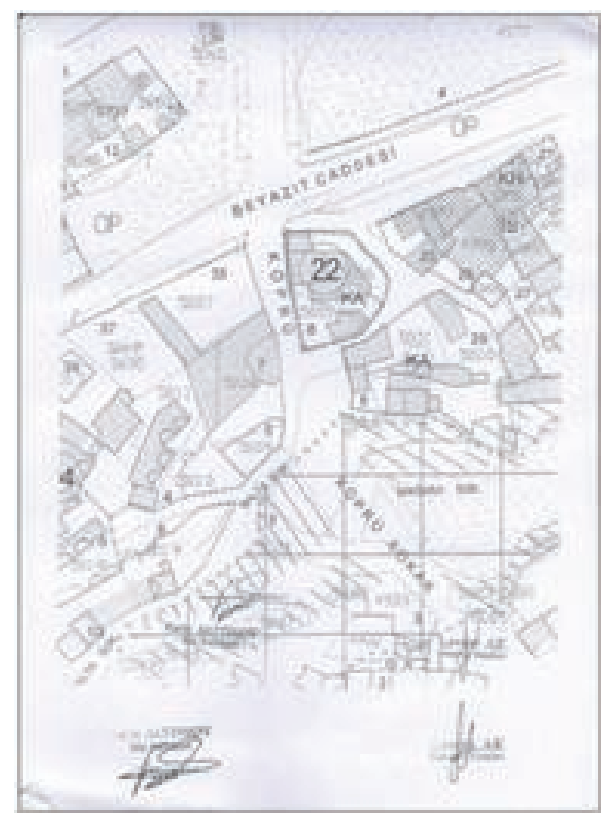

Figure 9. Cadastral Map Sheet of the Building(Archive of Nevşehir Cultural Heritage

\section{Conservation District Committee)}

Within the framework of the Mustafapaşa Conservation Development Plan, the building that is the subject of the present study remains within the protected urban areas and areas whose architectural and textual charac- ters are to be preserved. ${ }^{7}$ Given these data, two-term restitution projects were prepared; one for the " 1878 period" and the one for the "post-1878 period".

$\overline{7}$ In the KAIP plan notes, the spaces whose architectural and textual characters will be conserved are shown as KA (NKVKK archive). 


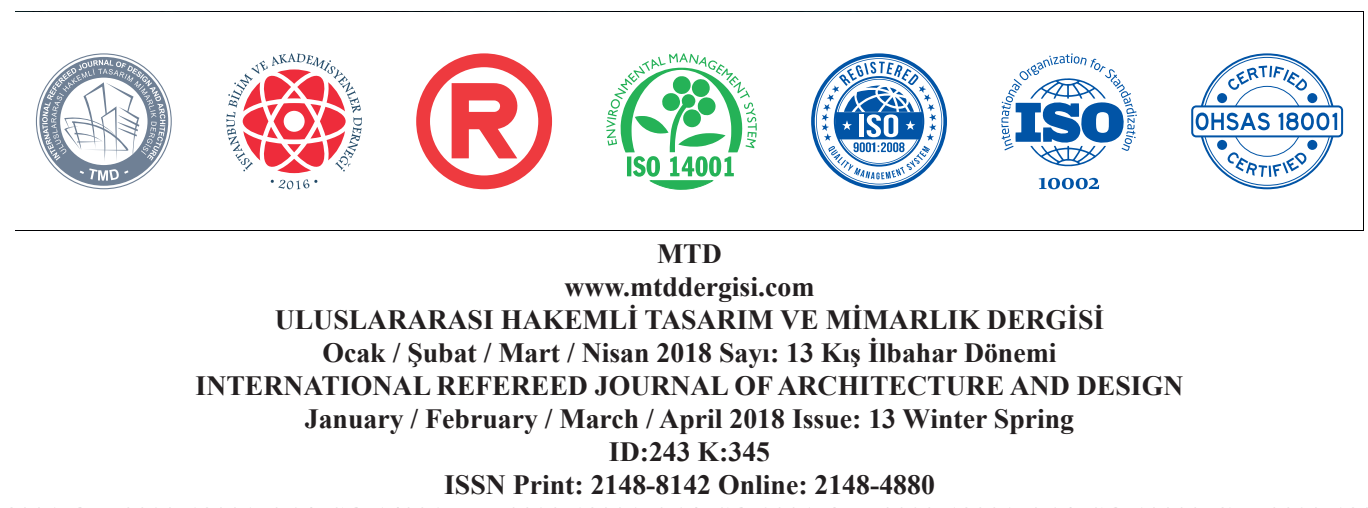

ISSN Print: 2148-8142 Online: 2148-4880
(ISO 18001-OH-0090-13001706 / ISO 14001-EM-0090-13001706 / ISO 9001-QM-0090-13001706 / ISO 10002-CM-0090-13001706)

(Marka Patent No / Trademark)

$(2015 / 04018-2015 / G E / 17595)$

\section{$1^{\text {st }}$ Period Restitution (1878 period)}

Above the entrance of the lower courtyard the construction date of the building, H.1235 M.1878, of the building is inscribed. Hence, it is considered that the initial building consisted of the lower courtyard walls, the rock room areas and the cut stone porches in front of these areas (Fig. 10).

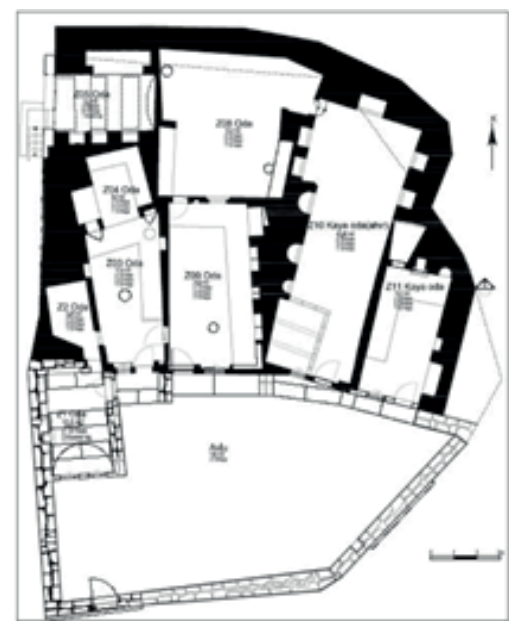

Figure 10. 1st Period Restitution Plan of Lower Elevation (-3.26)

Furthermore, the traces of the building indicate that there was a row of archaded porch in front of the rock rooms overlooking the courtyard (Photo 4). Room Z01 which is made of cut stone, was added later in front of the rock rooms and was used as a summer kitchen. The room covered with a barrel vault that was supported by three arches. According to the arch traces from the building, the barrel vault cover was completed. Room Z08 was a grape juice room is concluded based on the basin carved out of ignimbrite rock. Because the western wall of room Z05 was demolished, it was not clear whether there was an entrance door together with a window on this wall. It was thought that the area could have been used as a warehouse because it was 1.16 $\mathrm{m}$ below the elevation of the road. Additionally, it was determined that room Z10 was used as a barn based on the niches and chain rings used for the feedboxes on the walls (Photo 15). 


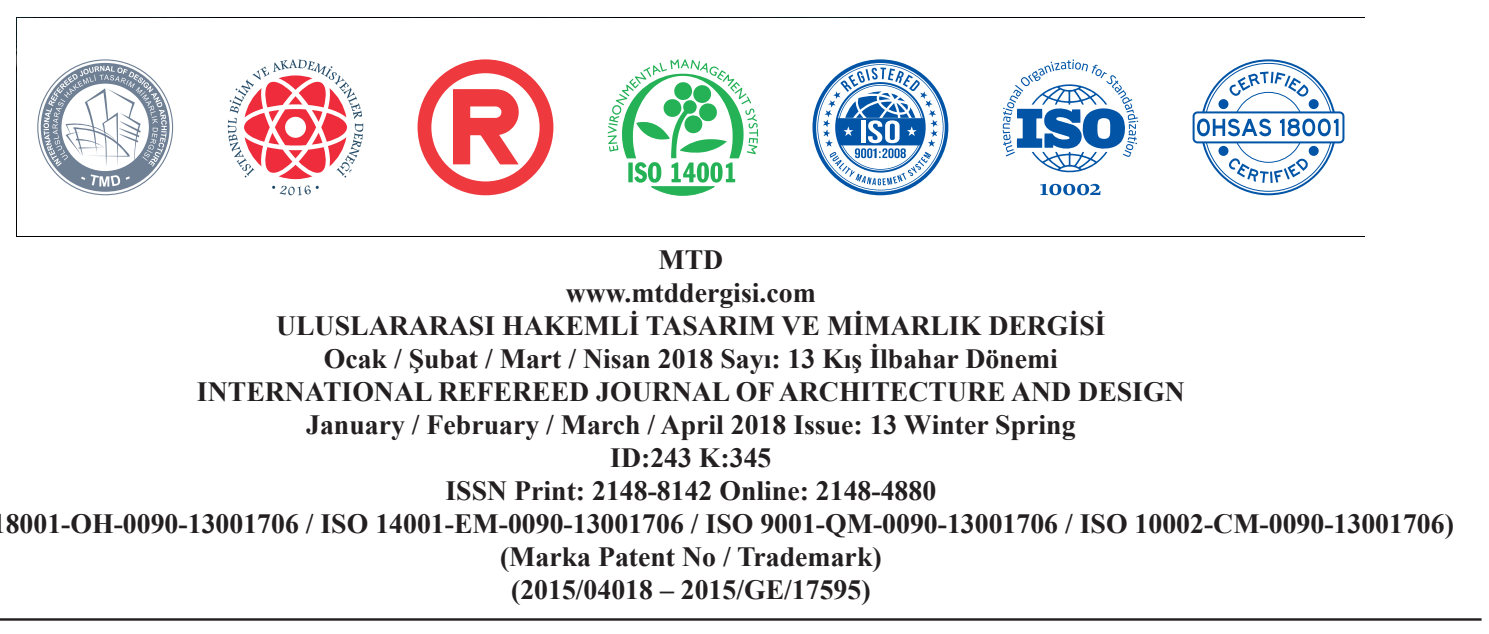

(ISO 18001-OH-0090-13001706 / ISO 14001-EM-0090-13001706 / ISO 9001-QM-0090-13001706 / ISO 10002-CM-0090-13001706)

Marka Patent No / Trademark)

$(2015 / 04018-2015 / G E / 17595)$

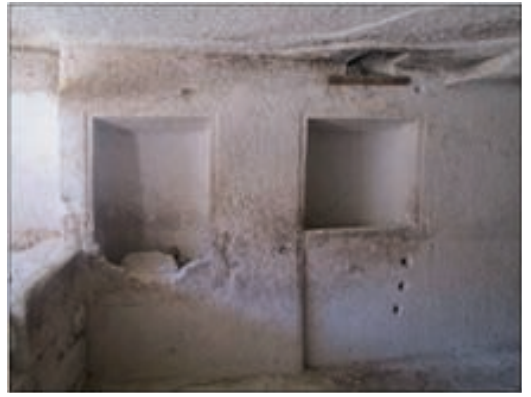

\section{Photo 15. Niches and Chain Rings in the Room Z10 Used as a Barn}

It is determined, based on the old pictures that there was a fireplace made of cut stone on the north wall of room Z11 (Photo 16). Since it is concludeds that this door that allowed passage from room Z11 to room Z10 was later opened, it was removed from the restitution project.

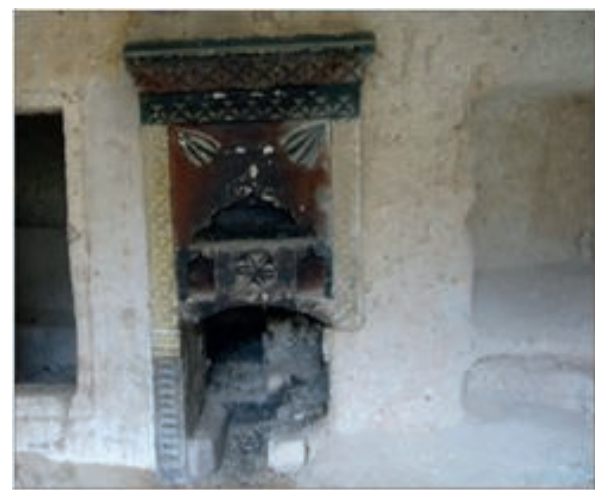

\section{Photo 16.Original Photo of the Fireplace (Archive of Nevşehir Cultural Heritage Con- servation District Committee)}

\section{$2^{\text {nd }}$ Period Restitution (Post-1878 Period)}

During the $2^{\text {nd }}$ period of the building, which followed the 1878 period, it is thought that the upper courtyard and the cut stone spaces were added as the needs arose. It is further concluded from the dilatations between rooms 101,102 and 106 that they were constructed at different times.
New rooms were added to the layout as the need for the rooms arose. Room 101, which was located on the western side, had a wooden ceiling. It was surmised that this was the first room to have been built due to the thick wall that was needed to provide support for the arch that was implemented in the other vaulted rooms. 


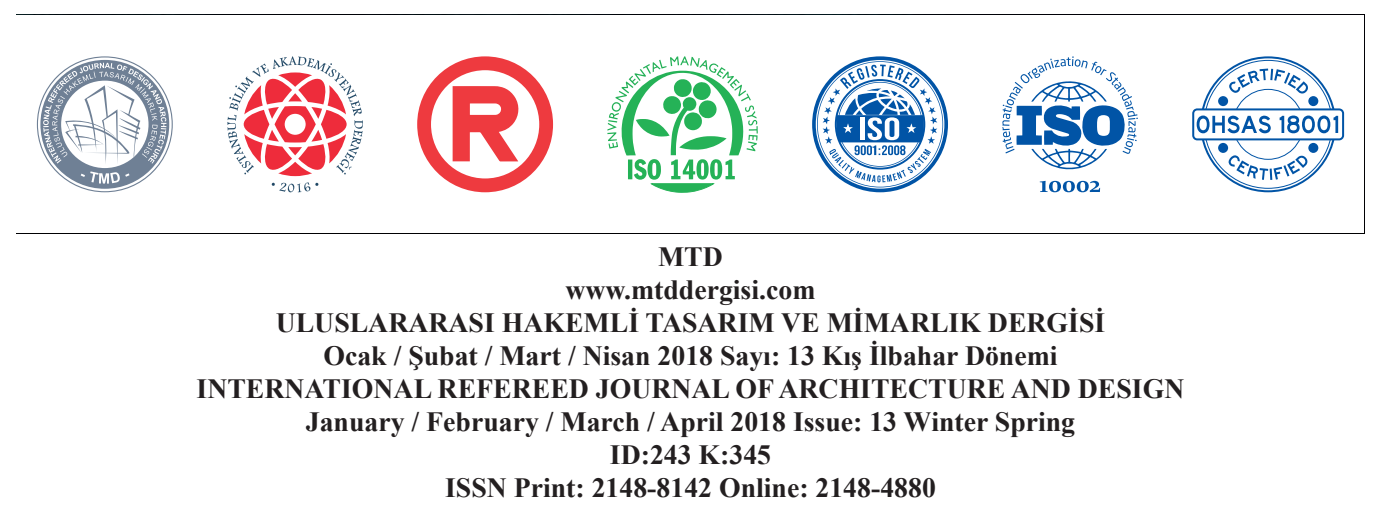

(ISO 18001-OH-0090-13001706 / ISO 14001-EM-0090-13001706 / ISO 9001-QM-0090-13001706 / ISO 10002-CM-0090-13001706)

(Marka Patent No / Trademark)

$(2015 / 04018-2015 / G E / 17595)$

Room 101 is the first room to be built at the upper elevation. It has a wooden lath ceiling, and is concluded from the traces that the window on the northern wall of room 102 was later reduced in size, although originally it was a larger window. Rooms 103, 104 and 105 , which were used as a toilet, a poultry house and a room were then added to the upper courtyard when there was a need for them. Room 106, which was arched and had a window on the east wall was drawn from the traces and the two windows on the west wall were drawn according to the comparative study of the building.
There is a cut stone wall between room Z06, i.e.,-haystack- and room Z08,i.e.,-grape juice room- which is thought to have been built later for hygienice purposes. Furthermore, old pictures indicate that rooms Z12 and Z13 were constructed on the southern side of the courtyard using a single layer of cut stones. Since there was a single-raw wall and there were no traces of an arch, it is believed that these rooms were covered with wooden rafters. There are two niches on the south wall of room Z12 and three on the south wall of room Z13. It is possible that these places were added to the lower courtyard in the post-1878 period (Photos 17 and 18).

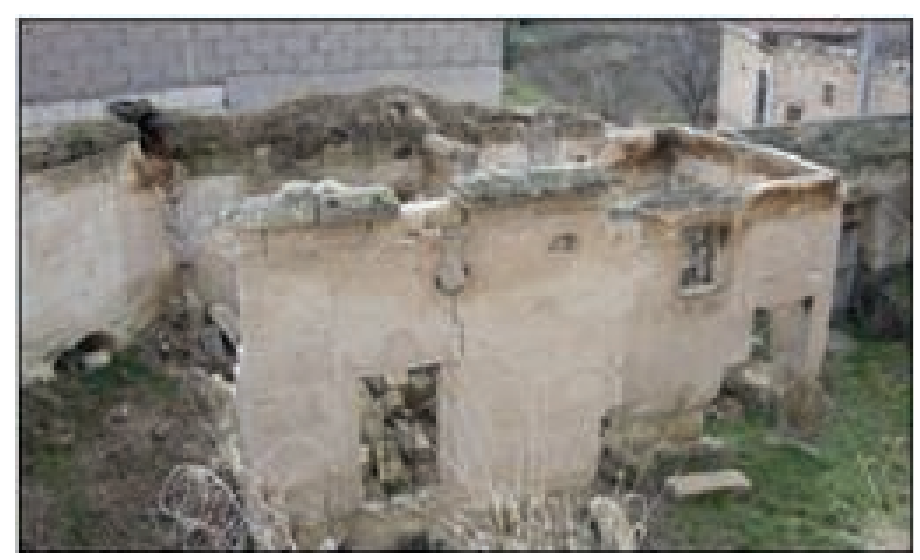

Photo 17. South Wall of the Lower Elevation of the Courtyard (Archive of Nevşehir Cultural Heritage Conservation District Committee) 


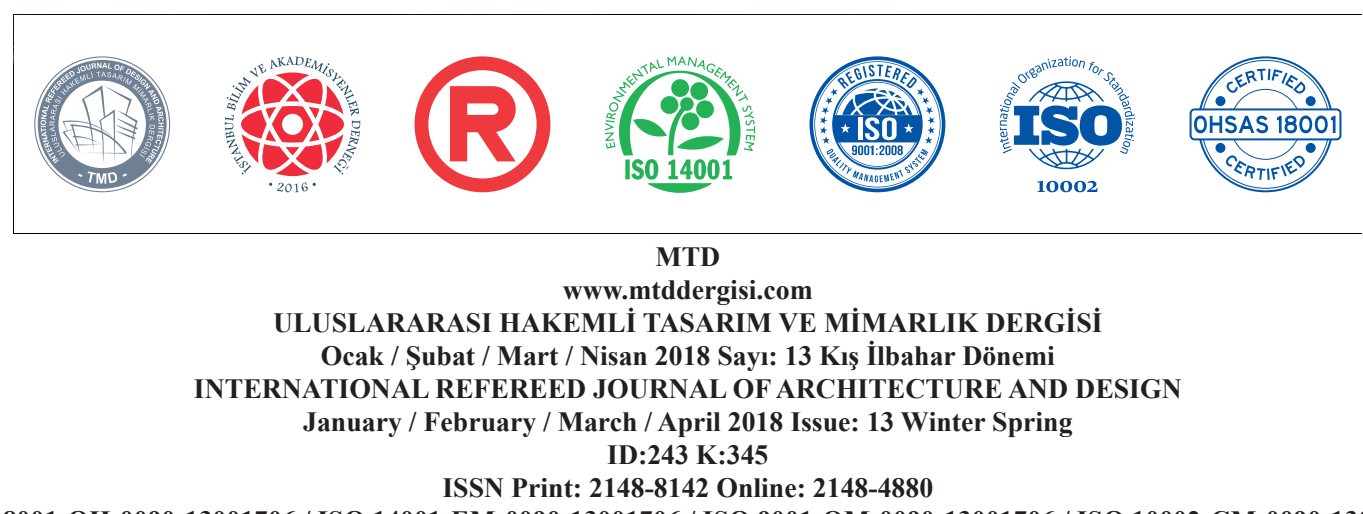

ISSN Print: 2148-8142 Online: 2148-4880

(ISO 18001-OH-0090-13001706 / ISO 14001-EM-0090-13001706 / ISO 9001-QM-0090-13001706 / ISO 10002-CM-0090-13001706)

(Marka Patent No / Trademark)

$(2015 / 04018-2015 / G E / 17595)$

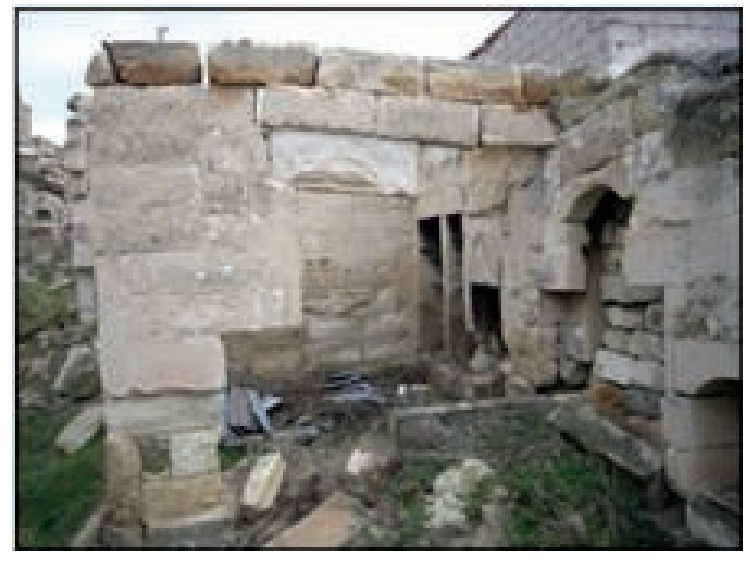

Photo 18. South Wall of the Lower elevation of the courtyard (Archive of Nevşehir Cultural Heritage Conservation District Committee)

Old photographs dated 2015 obtained from the archive of the Directorate of Nevşehir Regional Cultural Assets Preservation Board reveal that room $\mathrm{Z} 14$ which is made of cut stone is outside the property limits and that, furthermore, this room was used as a toilet (Photos 19-20).

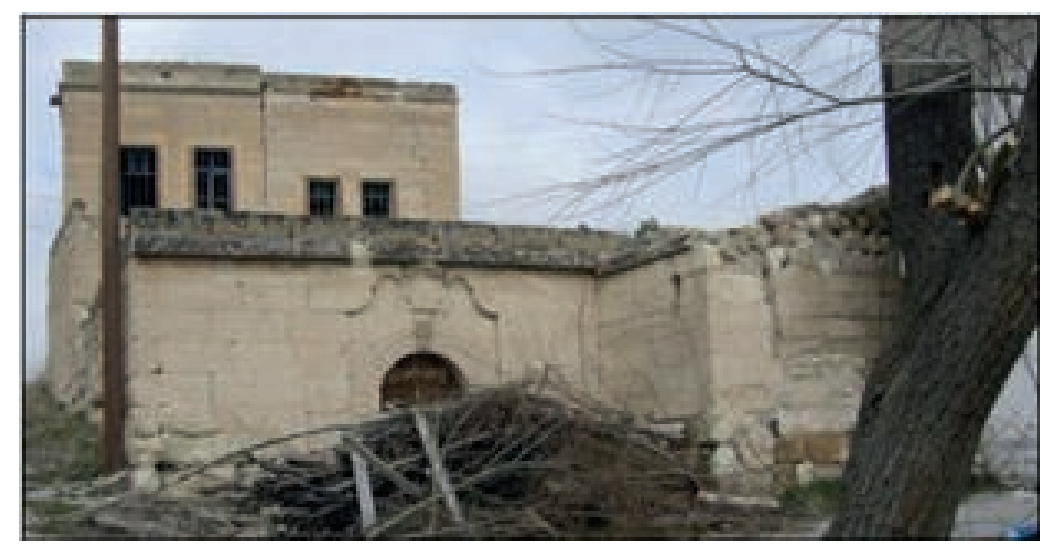

Photo 19. The Toilet of the Building at the south Façade (Archive of Nevşehir Cultural Heritage Conservation District Committee, 2015) 


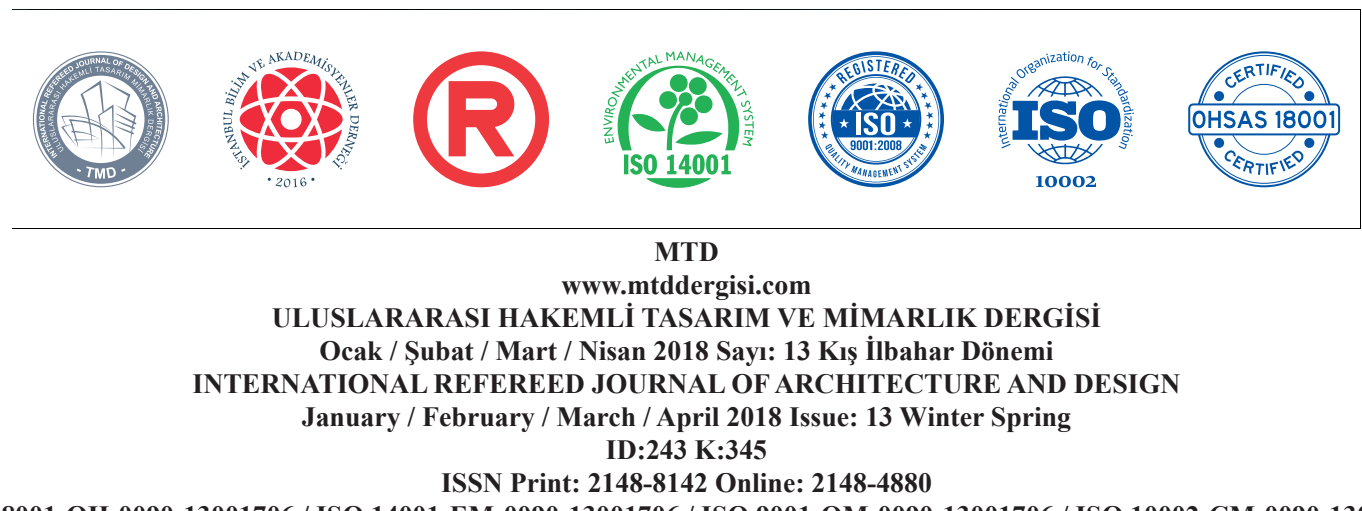

ISSN Print: 2148-8142 Online: 2148-4880
(ISO 18001-OH-0090-13001706 / ISO 14001-EM-0090-13001706 / ISO 9001-QM-0090-13001706 / ISO 10002-CM-0090-13001706)

(Marka Patent No / Trademark)

$(2015 / 04018-2015 / G E / 17595)$

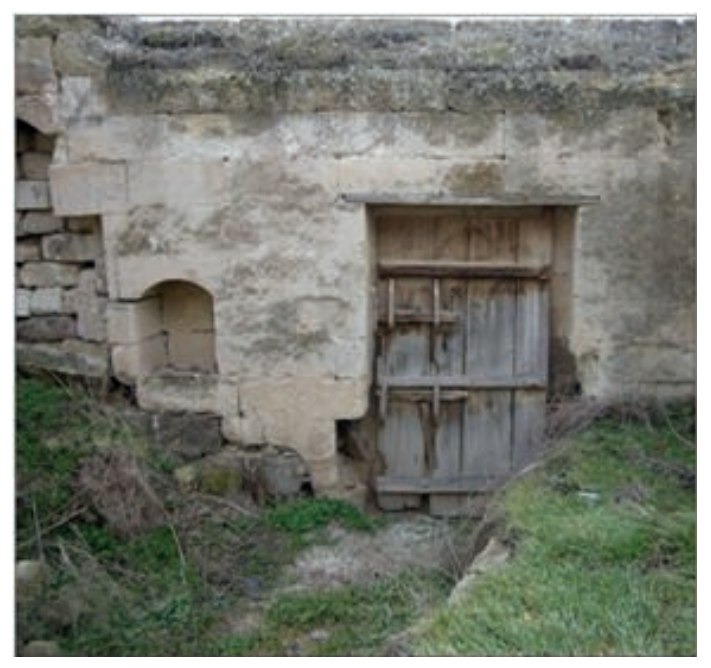

Photo 20. The Timber Door of the Toilet (Archive of Nevşehir Cultural Heritage Conservation District Committee)

It is evident from the traces that the lower courtyard and the upper courtyard are connected to one another by a staircase located on the southeast side of the lower courtyard.
It is further determined that the courtyard entrance door in this section opens to an intermediate landing of this staircase (Photo 21).

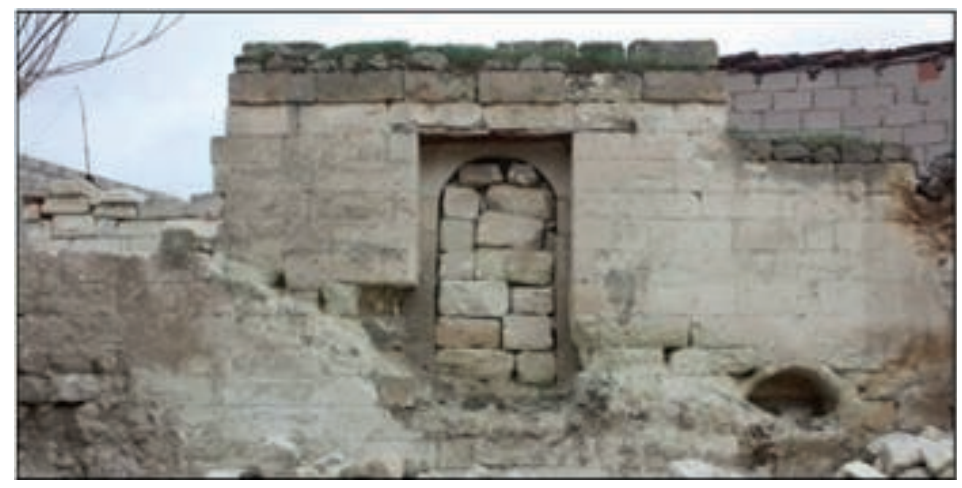

Photo 21. The Trace of the Stairs on the Courtyard Wall

According to the starting point and the dimensions of the arch springer stones from the collapsed staircase in room 106, which is in ruins today, it was proposed that on the north- ern facade be completed first as there was, no window designed for the northern façade. The courtyard entrance gate constructed completely of cut stone and the replacement of the 


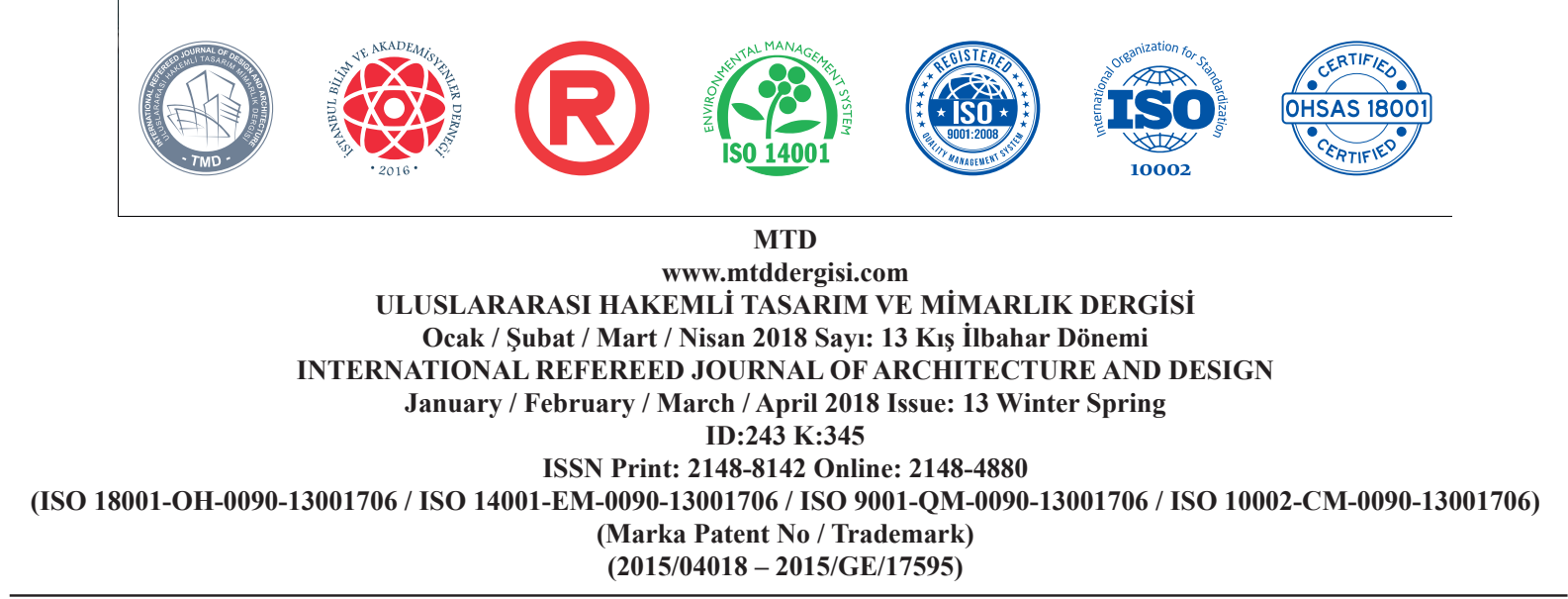

stone in the courtyard wall were completed using traces obtained from the building.

The moulding and gargoyle details visible on the western facade were completed based on the traces coming from the building, and the closed window of room 101 was reopened. On the western facade of room 106, two windows were proposed that would actually, make use of the existing windows in the building. The round arched door, which was later closed on the southeast facade of the courtyard, was opened and a window was proposed for the eastern facade of room 106 based on the traces from the building. Despite three arch springer stones on the eastern facade of room 2 and the presence of a niche generating the possibility of the presence of a building being in the past, an on-site examination found no building trace.

There are no major interventions on the facades that can cause changes. Because the construction systems of rooms 101 and 102 facing the southern facade of the building are different from each other, it is thought that room 102 was added to room 101 in case of need. The entrance gate located on the south facade is a wooden single-wing door and it is understood from old photographs that depicting the area east of the entrance that the toilet was in this location.

\section{Conservation Project}

The location of the site, the architectural, historical and documentary values create a great potential for economical, cultural and touristic activities. The traditional pattern, houses and monuments haven't lost their characteristics due to slow change in town center. This creates a great potential for town center.

The conservation project for this building was prepared in accordance with the structural evaluation and material problems according to its new function. For the building to sustain its originality, a re-use with a new function was suggested, and the project included cleaning, reinforcement, consolidation, renewing and rebuilding. The "genuineness" or "authenticity" introduced at the 1994 Bergen and Nara Conferences was considered to be the most important factor in architectural preservation and the most important criterion for determining conservation principles. ${ }^{8}$

\section{Reinforcement}

With respect to the cracks and joint discharges observed in the stone walls, the first step is to clean the surface joints. The mortar of stone fractures+lime used in the region is a local specialty. For this reason, original mortar mixture of suitable ratios according to the

8 http://www.icomos.org.tr/Dosyalar/ ICOMOSTR_0901543001353670596.pdf 


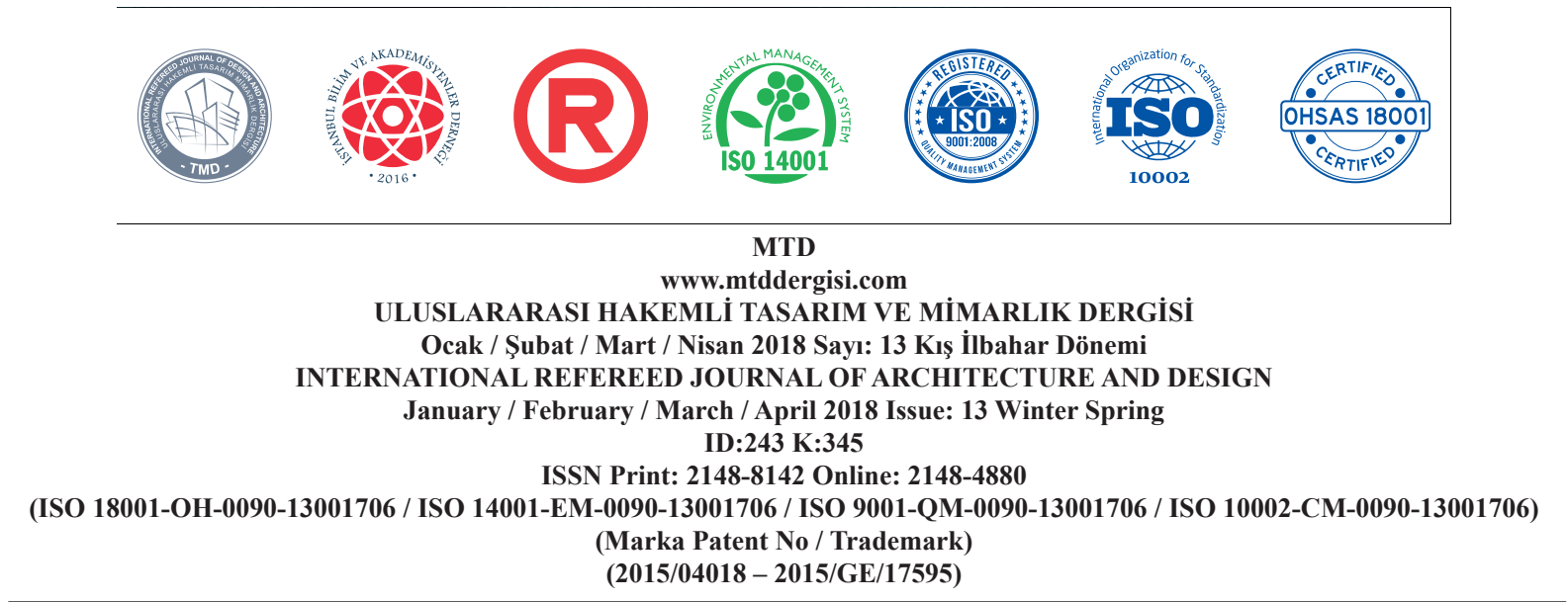

results of the material analysis. In many parts of the building, especially in the cut stone and rubble stone surfaces that make up the courtyard wall, there is a depletion of elements due to dispersion, erosion or breakage. Plasticity will be implemented for surfaces where there is 0 to $5 \mathrm{~cm}$ of dispersion or erosion using a complementary mortar that is compatible with the original material to replace the decaying parts, plastic repair will be implemented to eroding surfaces exhibiting 10 to $15 \mathrm{~cm}$ of abrasion, and surfaces eroded to $15 \mathrm{~cm}$ or more should be replaced with block stones.

The courtyard door that opens to the stairway landing leading to the window of room Z09 and to the upper elevation courtyard was bonded and covered with cut stone. These new fillings will be dismantled to reveal the original gaps.

Because the building has not been used for a long time, dampness and water problems originating from the top cover have caused static problems such as cracks and splits in the rooms that are made up of cut stone on the upper floors. The cracks on the southern walls of the room on the upper floor, the split on the dilatation of both rooms on the upper floor, the crack on the western wall of room 101 and the crack and split on the south entrance door of the lower courtyard are among the main problems. Structural elements that have lost the bearing property and cannot ful- fil their functions must reinforced or replaced. In this regard, there should be collaboration with civil engineers. One of the methods to correct for the loss of bearing property is to determine the location of the stones where there was an initial split and assess the stones relationships with each other and then dismantle the area and reinstall and grout them.

Since the necessary insulation was not provided in the flat roofs of rooms 101 and 102, which were made of earth during a time when the adobe was not regularly maintained, it is evident that the timber ceiling of room 101 has decayed and rotted, the mortar plaster on the floor of room 102 has flaked off due to dampness, and the cut stones have begun to erode and dissolve. To overcome these problems caused by the upper cover, after the plant cleaning on the roof is completed, straw will be laid on top of the rubble filling and the insulation material will then be laid on top of that and covered with pebbles, mud and earth.

\section{Cleaning}

Worn surfaces and dirt will be removed from the structural elements by way of physical and chemical methods. The dirt and filth on corroding and ablating rock surfaces of the rocky areas in the lower courtyard, the dirt and blackening caused by smoke from fireplaces and indoor kitchens, the dirt on the wall surfaces of rooms 101 and 102 that have 


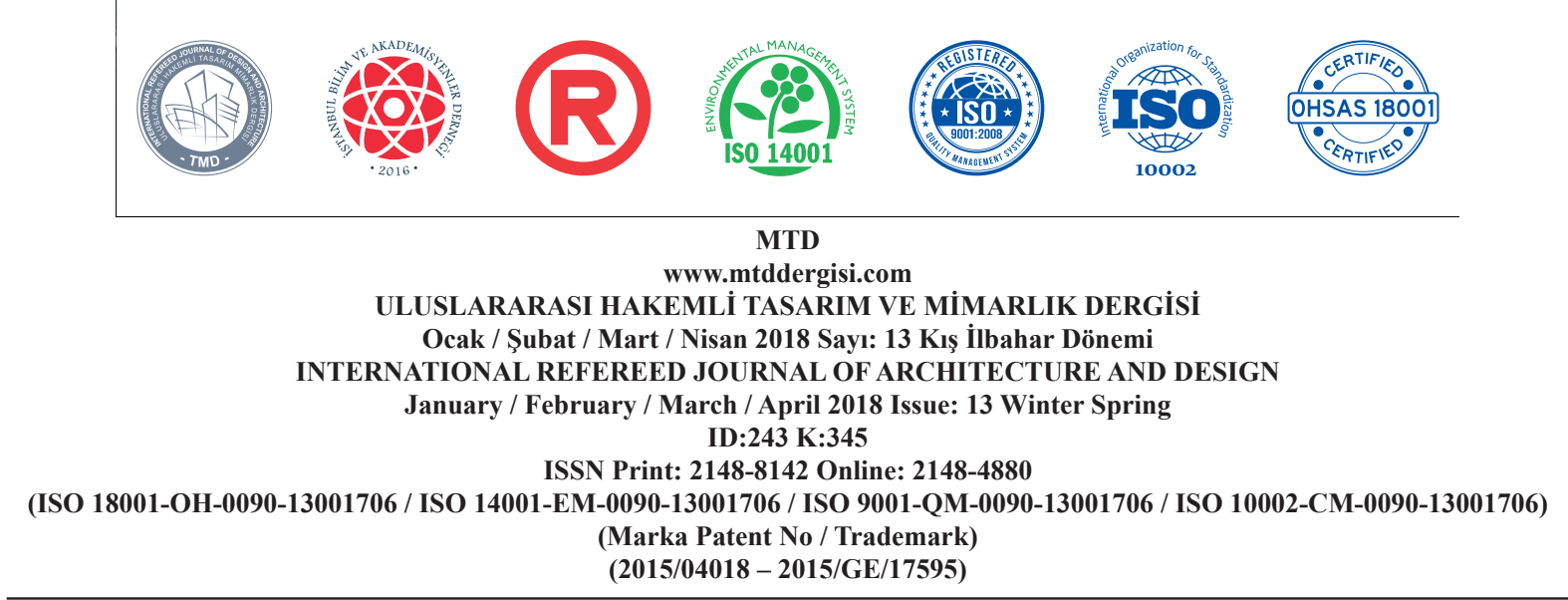

been whitewashed with lime and the dirt due to atmospheric conditions on the exterior facades of the stone surfaces will be cleaned by using wire brushes or tooth chisel. On the stone and rock surfaces of the building, there is vegetation;hence, the surfaces have experi- enced changes in colour caused due to leaking water. Accordingly, it is recommended that the plants and trees that have formed on the walls off the structure be removed in an appropriate way (Fig. 11).

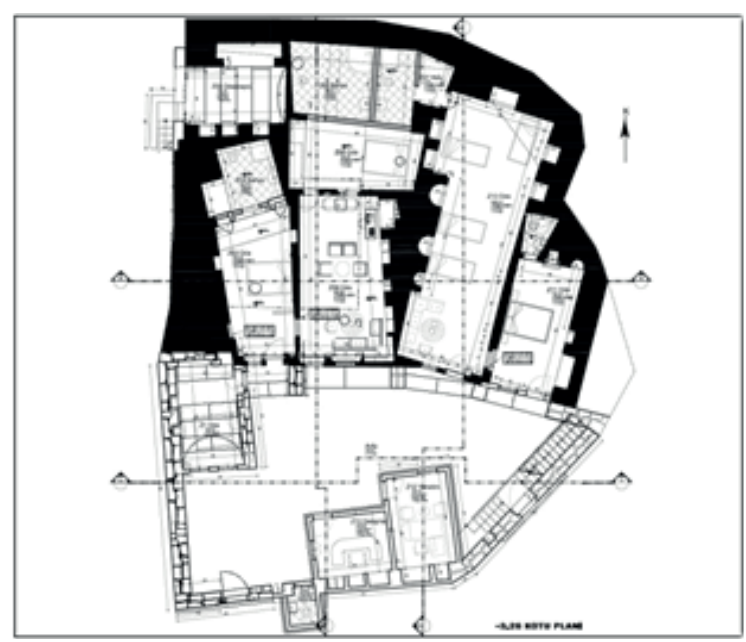

Figure 11.The Adaptive Re-Use Project of -3.26 Elevation

On the surfaces where there is blackening and excessive dirt, the methods determined by the experts will be applied to the surface under the dirt layer in a laboratory environment to prevent damage during the cleaning process. Cement blended joint applications that damage the original material will be cleaned by blasting and then protective joint material with original mortar will be applied. All wooden structural elements will be cleaned mechanically. Any insect activity that occurs in the wooden elements will be removed from the wooden materials by methods recommended by the experts. Wooden elements that have lost their structural property will be replaced by impregnated wood of the same variety, size and form in accordance with the details of the restoration project. Water-based varnish will be applied to the insect-free wooden elements in a solid state by impregnation in situ. To protect the metal elements in the construction from rust and corrosion, rust remover will be applied and covered with a protective paint.

\section{Reintegration}

The reintegration of the suggested restoration project with respect to the structural ele- 


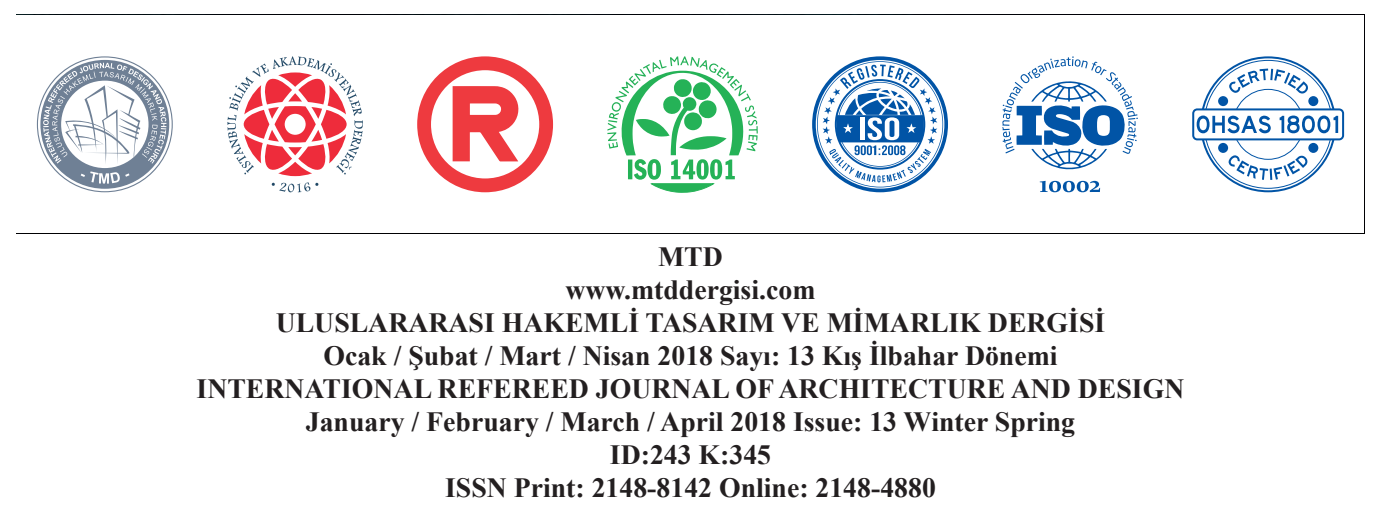

(ISO 18001-OH-0090-13001706 / ISO 14001-EM-0090-13001706 / ISO 9001-QM-0090-13001706 / ISO 10002-CM-0090-13001706)

(Marka Patent No / Trademark)

$(2015 / 04018-2015 / G E / 17595)$

ments in the building that have been damaged or destroyed will be conducted in accordance with the details of the restitution project and prepared using traditional materials, traces from the building, comparative repair works, oral sources and similar period structures

(Fig. 12).

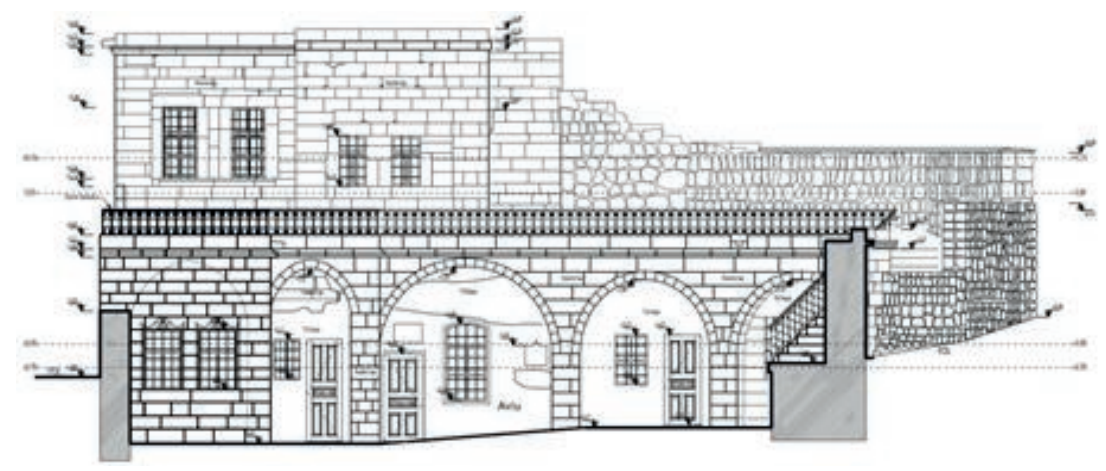

Figure 12. C-C Section

The missing upper wall and arched top cover of the room Z01 will be completed, and the demolished western wall of room Z05, which has an entry from the gateway will be rebuilt. Furthermore, the dismantled kitchen stove on the northern wall of room Z11 will be rebuilt from cut stone, the entrance wall, which is essentially demolished, will be rebuilt from cut stone and the door and window gaps, as indicated in the restoration project, will be left untouched. Rooms Z12 and Z13 which are located to the south of the lower courtyard will be rebuilt, as presented in the restitution project, and the arched porches, which once existed in front of the rock rooms but are now destroyed, will be rebuilt. The missing western and northern walls and arched ceiling of room 106 will be rebuilt. The stairway leading to the upper level. With respect to the courtyard, the floor will be covered with natural stone, the demolished entrance gate to the upper level of the courtyard will be completed, a capstone will be placed on the courtyard wall and rooms 103, 104 and 105 will be dismantled and rebuilt.

\section{Recommendations for the New Use}

Located on the tour route of foreign tourists, the village of Mustafapaşa in the Ürgüp district of the Cappadocia region is an important settlement centre, due to its architectural and historical values. In accordance with the needs of local residents and, as an example of civil architecture, it was approved that the lower elevation courtyard could be reconstructed to function as a café and restaurant 


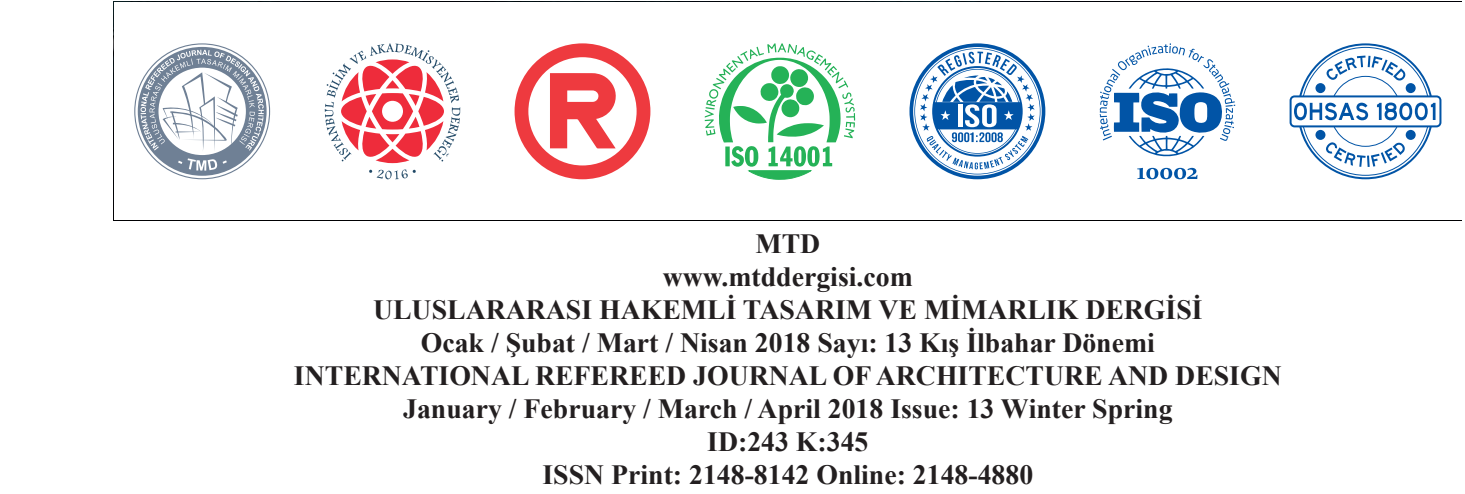

(ISO 18001-OH-0090-13001706 / ISO 14001-EM-0090-13001706 / ISO 9001-QM-0090-13001706 / ISO 10002-CM-0090-13001706)

(Marka Patent No / Trademark)

$(2015 / 04018-2015 / G E / 17595)$

for hotel guests as well as for local residents and the general public.Accordingly, the following transformations and reconstructions are recommended.

It is recommended that the spaces at an elevation of -3.78 be transformed into bedrooms for the boutique hotel. The missing walls and the arched top cover of room Z01 will be completed and converted into a bedroom, the window opening that faces room Z02 will become a door that links Z01, the bedroom, to room Z02, the restroom/washroom. The doorway connecting this bathroom, i.e., room Z02 to room Z03 will be bonded and covered with cut stone and then plastered with original ignimbrite rock dust. The floor and walls of the bathroom will be covered with ceramics tiles up to height of $80 \mathrm{~cm}$ from the ground.

The ceiling of the bathroom, i.e., Z02 which is $+1.78 \mathrm{~m}$. high will be filled and extended to a height of $+2.00 \mathrm{~m}$. The doorway to room Z03, which allows access to room Z09 will be covered with stone and plastered with ignimbrite rock dust. Of the window located on the east side will be made into a doorway that will allow access to an independent hotel room. The eastern wing of the ignimbrite rocks floor will be filled, covered with natural stone and room $\mathrm{Z} 04$ will be converted into as a bathroom. The floor and walls of room Z04 will be covered with ceramic tiles up to a height of $80 \mathrm{~cm}$ from the ground (Fig. 13).

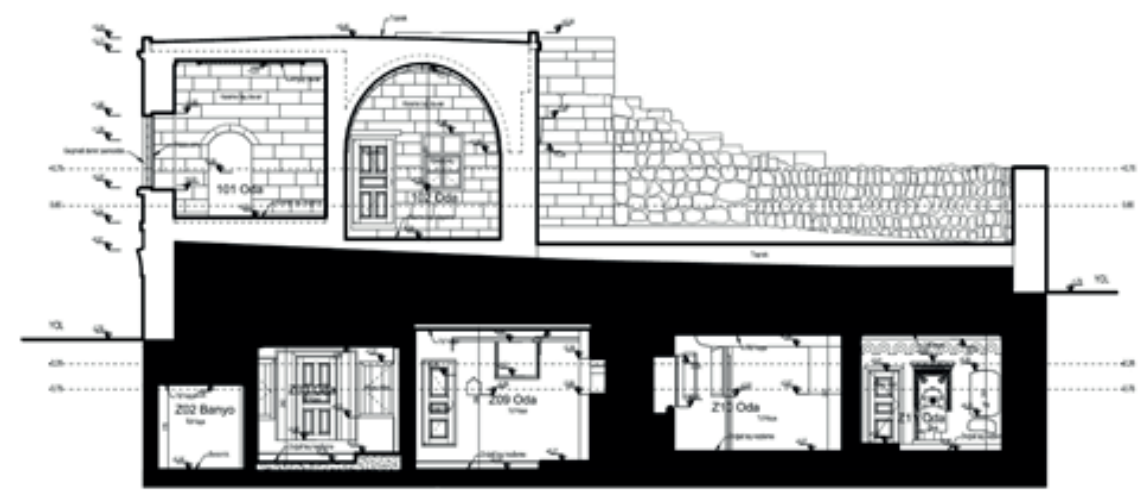

Figure 13. A-A Section

Rooms Z06, Z08 and Z09 are intended to be connected to one another to create a single hotel room. Room Z09 will function as a sitting and resting area and will be part of room
Z08, which will be converted into a bedroom. The window opening in the cut stone wall separating rooms Z06 and Z08 was converted into a door to allow access between the two 


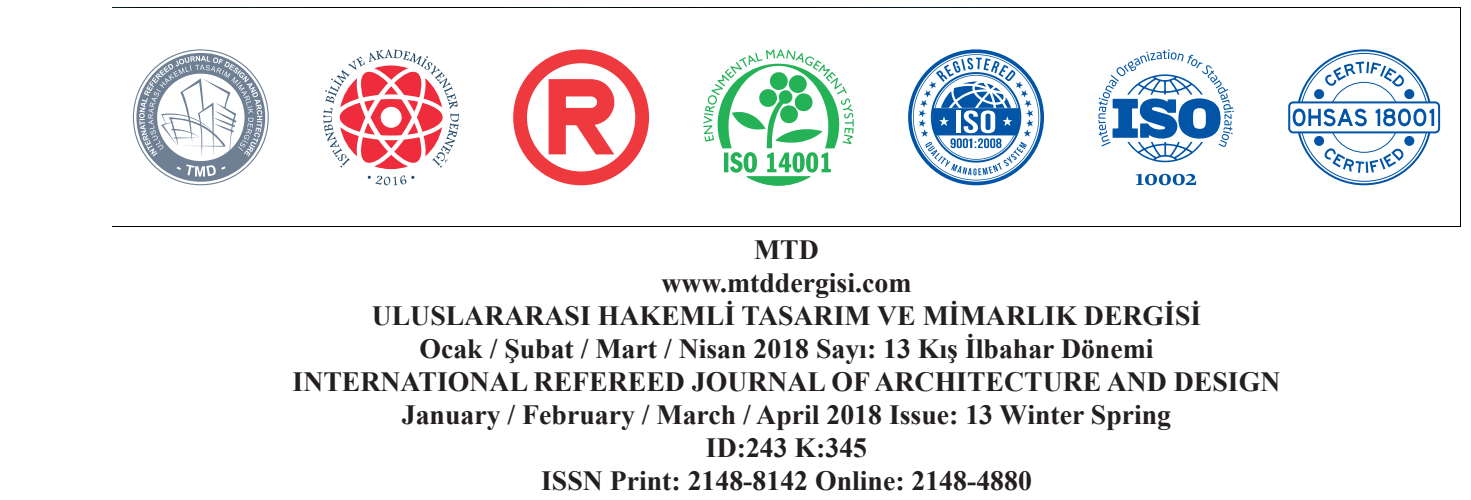

(ISO 18001-OH-0090-13001706 / ISO 14001-EM-0090-13001706 / ISO 9001-QM-0090-13001706 / ISO 10002-CM-0090-13001706)

(Marka Patent No / Trademark)

(2015/04018 - 2015/GE/17595)

rooms. Room Z06 which has no source of illumination and isn always in darkness will be divided into two parts with a cut stone wall separating one part of room Z06 into a washroom/restroom as detailed in the restoration project. The original rock walls and ceilings will be preserved and the floor will be covered with natural stone. The floors of the bathrooms in Z06 will be covered with ceramic tiles and the walls will be covered with ceramics up to $80 \mathrm{~cm}$ in height from the ground (Fig. 14).

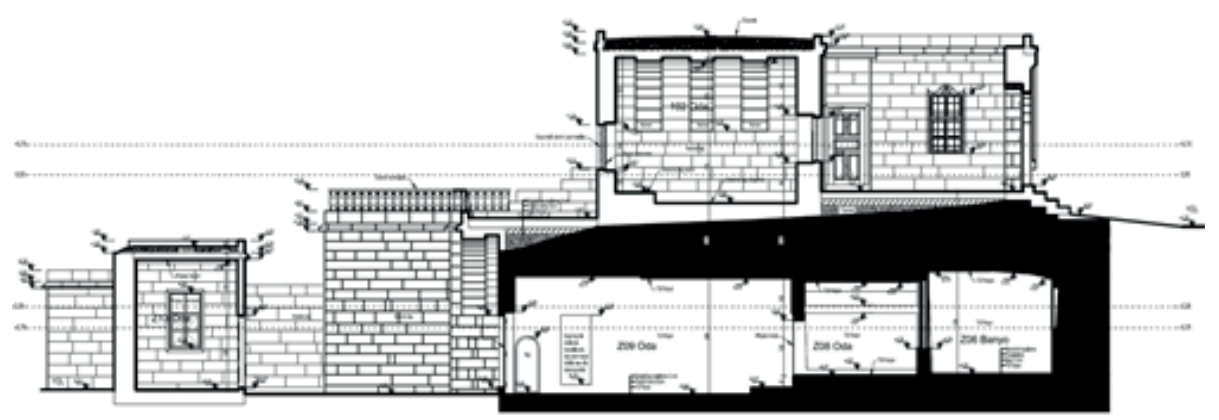

Figure 14. B-B Section

Room Z10 will be converted to a hotel room, and thus the feedbox constructed of cut stone located to the west of the entrance will be dismantled. The ignimbrite rock surfaces that have dissolved and decayed due to the room's previous use as a barn will be dented using a tooth chisel. The floor will be covered with natural stone, and the entrance door and window will be rebuilt with cut stone. The washroom/restroom will also be built in this room by dividing a part of the room Z06.

Room Z11 will be used as a hotel room. The fireplace in the northern wall, which was dismantled, will be rebuilt from cut stone in accordance with the details of the restoration project. The demolished entry wall will also be rebuilt from cut stone, and the doorway and window opening will be left untouched as indicated in the restoration project. Dissolving and eroding surfaces of the ignimbrite rocks on the walls of the room will be applied by a tooth chisel and the floor will be covered with natural stone. The large niche in the northern part of the room will be converted into a bathroom.

The Z12 and Z13 rooms on the southern side of the courtyard will be redecorated and used as the reception area. These spaces, originally constructed of single-layer cut stone and covered with wooden rafters, will be rebuilt according to the details of the restoration project.

Room Z14, which is constructed of cut stone and had been used as a toilet is located to the 


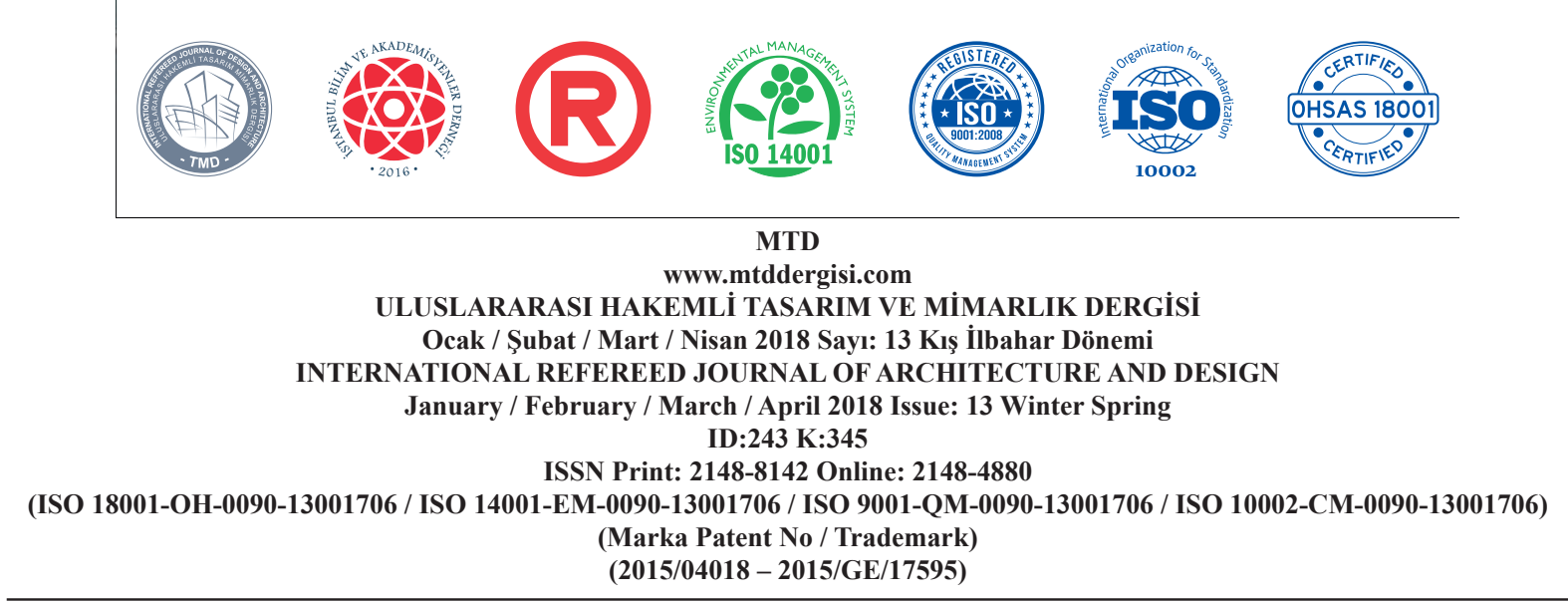

east of the lower courtyard entrance door, which is not present today but is known to have existed based on old photographs, will be converted it into a staff washroom/restroom according to the details of the restoration project. The floors and the walls of the bathroom, 1.e., Z14 will be covered with ceramics up to a height of $80 \mathrm{~cm}$ high from the ground. Room $\mathrm{Z} 05$ at an elevation -3.26 will be used as a warehouse. Accordingly, the dissolving and eroding surfaces will be dented and the floor will be covered with natural stone. The western wall of the warehouse area will be rebuilt and a staircase built of cut stone will be added to the front part of the room, elevating it to street level.

It was considered appropriate that the places located in the upper courtyard, i.e., at +0.75 elevation, will serve as a cafe and restaurant for not only the hotel guests but for the general public and local residents as well. The stairway leading up to the restaurant floor from within the hotel will be rebuilt according to the details in the restoration project. Those who are not hotel guests will be able to access the restaurant by the way of the upper elevation courtyard door. Furthermore, the missing western and northern walls together with the arched ceiling of room 106 will be completed, and the niches on the northern wall of room 101 have already been converted into a doorway and an access passage to room 106 has been incorporated. Rooms 101,102 and 106 will become dining and sitting areas. Room 103 is designated as the restaurant's storage area, whereas room 104 will become the male and female washrooms and room 105 will be the restaurant's kitchen. Room 104, which will be dismantled and reconstructed, has been spatially extended to meet its newly identified intended function.

\section{DISCUSSION}

The aim of the preservation is to achieve not only the conservation and revitalization of the buildings and historical settlements but also to achieve the sustainable participatory development of the villages for the future generations. Public participation is very important to achieve sustainable development. Local government and academia could organize educational seminars explaining the advantages of community involvement in these successful examples. Non-hierarchal partnerships between central and local governments community and non governmental organisations are fundamental for generating strategies and policies for a sustainable future.

\section{CONCLUSION}

Preservation of the architectural heritage is considered a fundamental issue in the life of modern societies. In addition to their historical interest, cultural heritage buildings are valuable because they contribute significantly to 


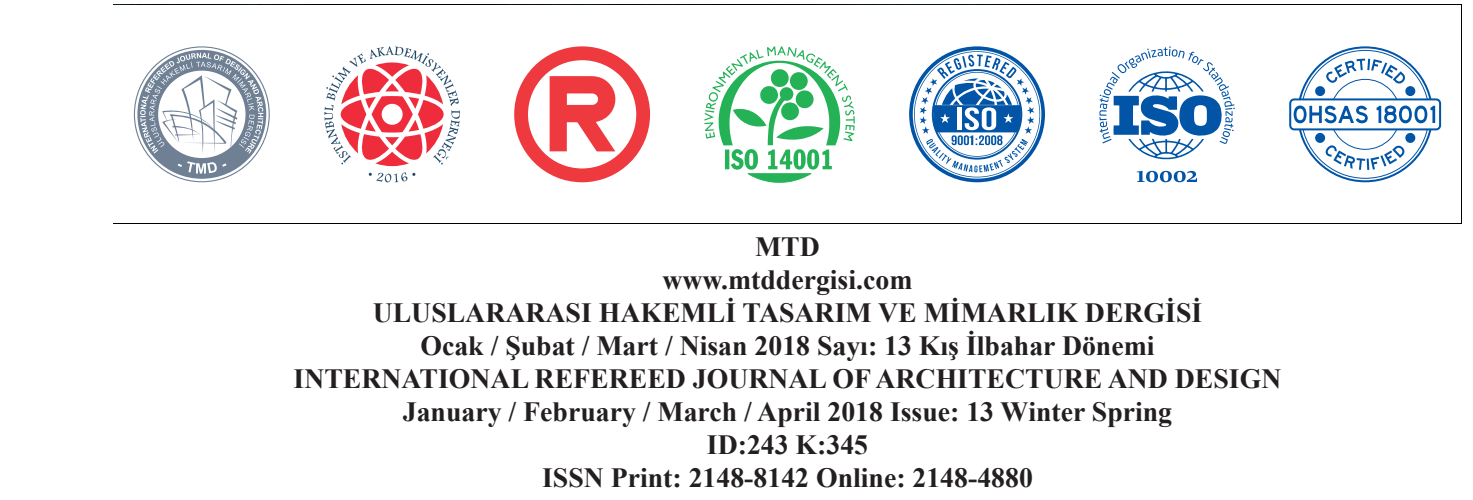

(ISO 18001-OH-0090-13001706 / ISO 14001-EM-0090-13001706 / ISO 9001-QM-0090-13001706 / ISO 10002-CM-0090-13001706)

(Marka Patent No / Trademark)

(2015/04018 - 2015/GE/17595)

the economy by providing key attractions in a context where tourism and leisure are major industries in the future. The need of preserving historical constructions is thus not only a cultural requirement, but also an economical and developmental demand. For that reason it is important to preserve the architectural heritage of Cappodocia.

The building currently undergoing restoration is one of the examples of the original civil architecture in which a combination of carved rock and stone techniques was used to reflect the local identity of the village of Mustafapaşa in the Urgup district of the Cappadocia region.

The original building elements of the Mustafapaşa houses, such as iwans, cantilevers and original stone workmanship were implemented according to the economic income of their owners. The carved rock units formed around the courtyard revealed a potential for growth over time, thereby creating a dynamic effect. With respect to the function of the building, re-use aimed at reintroducing the building into the region was proposed in accordance with the plan notes in the Provisions of Mustafapaşa Preservation Development Plan'. The function of the building, which is in

9 The Provisions of Mustafapaşa Preservation Development Plan notes it states, “...the fact that the historic buildings are dense; that the structures especially the outer space elements (facades, windows, doors, walls, etc.) will be conserved as loyal to their original texture; that the damaged elements will be repaired according to the original; they are textures to be intervened in a limited current use today, as a boutique hotel and cafe, was considered an approach that will address the needs of the local people and be effective in promoting tourism. By providing accommodations for tourists visiting the region, the building will provide visitors the opportunity of become more closely acquainted with the cultural values and architectural identity of the local people. Reflecting the original identity of the region, this building serves as an example of the restoration practices that will be implemented throughout the region.

To preserve and maintain the structure in the best possible way and in accordance with the universal preservation decisions, it was determined to modify its function and pass it on to future generations.

\section{RECOMMENDATIONS}

Mustafapaşa with its rapidly developing culture and its increase in tourism due to its historical features, is one of the most exceptional settlements in the of Cappadocia region. However the success of the conservation in the area depends on the quality of those projects and their applications of those projects. In addition

way. Since street locality and street gauges are also intended to be conserved, the environment will be taken into account in all interventions. In any operation on the block of the structure (restoration, reconstruction and / or new structure), with the 1/500 scaled detection and investigation of all the block and the determination of indoor and outdoor locality of the block (street silhouettes, sections of courtyards, etc.) are used as the bases of the projecting process. 


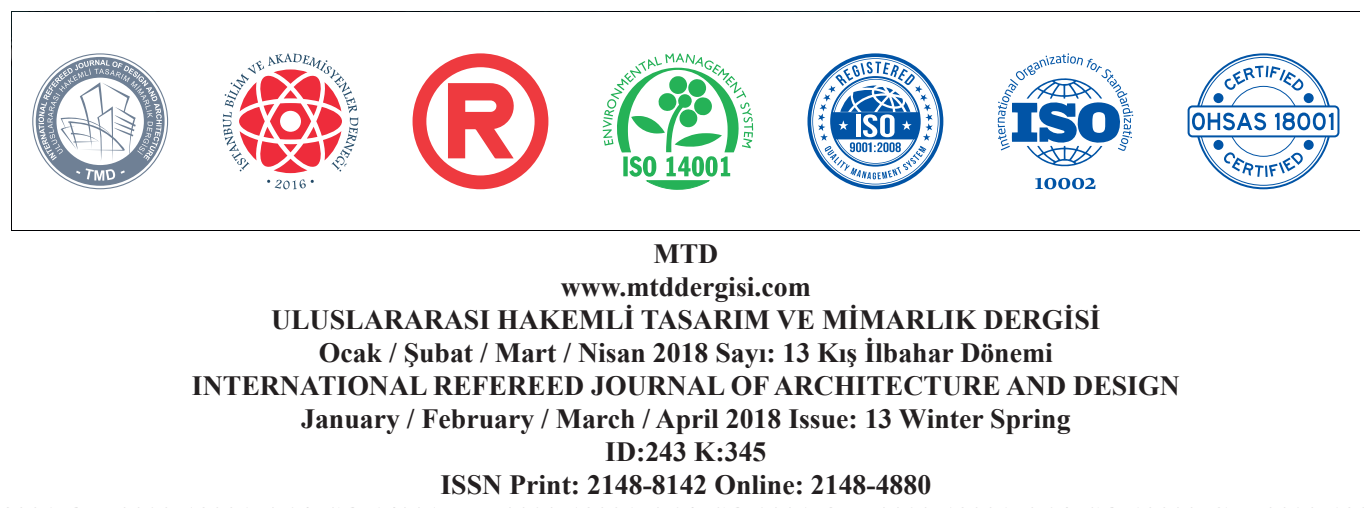

(ISO 18001-OH-0090-13001706 / ISO 14001-EM-0090-13001706 / ISO 9001-QM-0090-13001706 / ISO 10002-CM-0090-13001706)

(Marka Patent No / Trademark)

$(2015 / 04018-2015 /$ GE/17595)

to all, the aim of the preservation is also to achieve not only the conservation and revitalization of the buildings but also to achieve the sustainable participatory development models of the whole village for the future generations. $\mathrm{Su}$ et al.2018 indicate that a cultural political economy "framing" for interpreting heritage tourism in urban contexts. Key ideas behind this research perspective are explained and illustrated through discussion of past research studies of urban heritage tourism.

\section{ACKNOWLEDGEMENTS}

This is a master's thesis titled "Restoration Project of a Civil Architectural Example of a Structure in section 42 and parcels 5005 and 5006 in the Village of Mustafapaşa located in the region Cappadocia". It is to be presented to the Department of Restoration Science at the Department of Architecture of Uludag University Faculty for approval by the Institute of Natural and Applied Sciences under the subject " $31037515-302.15$ / 2429" dated 22 March 2017.

\section{REFERENCES}

BALTA, E., (2007). Sinasos, a Cappadocia Town Before Excahange (Ed.), İstanbul, Türkiye: Bir Zamanlar Publications, pp. 240

ERENCIN, A., (1979). An approach to Urban Renewal Studies For Tourism in Cap- padocia local housing: Avcilar Village. İstanbul, Türkiye: PhD Dissertation, Istanbul Technical University Natural Science and Technology Institute, Architectural Department

MUSTAFAPASA LOCAL AGENDA 21 CITY COUNCIL, (2007). Current Status Report and Action Plan of Cappadocia's Sleeping Beauty: Mustafapaşa, Sinasos, Kayseri. Türkiye:2. Basım. M Grup Printing

ROIDES, S.R., (1985). Sinasos Houses: Sinasos in Cappodocia. Londra, pp.113-160

STEA, D.,TURAN, M., (1993). Placemaking: The Production of Built Environment in two Cultures, G.Britain, pp. 382

NEVSEHIR CULTURAL HERITAGE CONSERVATION DISTRICT COMMITTEE archive

GUCHAN, N.Ş., (2012). Kayakap1 Cultural and Natural Environment Preservation and Revitalization Project. Kayakapı Bulletin:2

IDIL, A., IDIL, H., (2004). Explanatory Report of Provisions of Mustafapaşa Preservation Development Plan.Th. \& İdil Architectural Office, Ankara

SOLMAZ, F., (2013). Construction Techniques of Traditional Houses in Nevşehir; Case Study on Ürgüp, Mustafapaşa and 


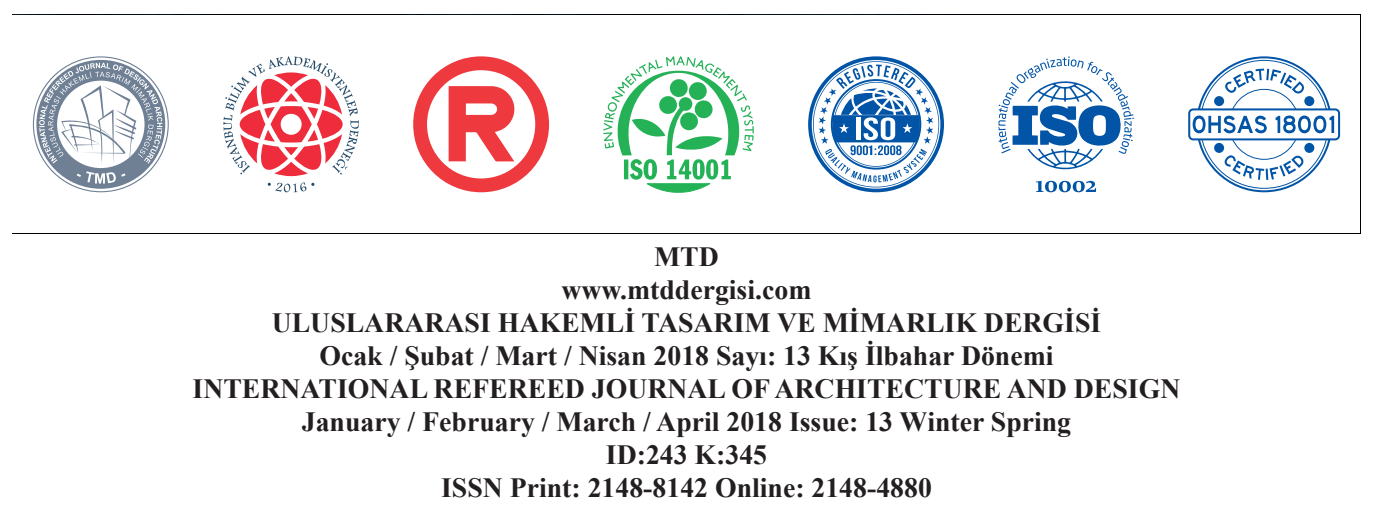

(ISO 18001-OH-0090-13001706 / ISO 14001-EM-0090-13001706 / ISO 9001-QM-0090-13001706 / ISO 10002-CM-0090-13001706)

(Marka Patent No / Trademark)

$(2015 / 04018-2015 / G E / 17595)$

İbrahimpaşa. Master's thesis, Middle East

Technical University, Graduate School of

Natural and Applied Sciences, Architec-

tural Department,Ankara

ERENÇİN, A., (1979). Kapadokya Yerel

Konutlarında Turizme Yönelik Yenileme

Çalışmalarına Bir Yaklaşım: Örnek

Avc1lar Köyü, unpublished $\mathrm{PhD}$ thesis,

Istanbul Technical University, Graduate

School of Natural and Applied Sciences,

Architectural Department, İstanbul

AKMAN, S.T., (1985). The Preservation and Rehabilitation Project of "Yeni Mahalle", Mustafapaşa, Unpublished Master's thesis, Middle East Technical University, Graduate School of Natural and Applied Sciences, Architectural Department, Ankara

BINAN, D.U., (1994). Güzelyurt Örneğinde, Kapadokya Bölgesi Yığma Taş Konut Mimarisinin Korunmasi İçin Bir Yöntem Araştırması, unpublished $\mathrm{PhD}$ thesis, Yıldız Technical University, Graduate School of Natural and Applied Sciences, Architectural Department, İstanbul

TEKIN, N.E., (2009). MustafapaşaHaralambos Sultanidis House Restoration Project, Master's thesis, Istanbul Techni- cal University Graduate School of Natural and Applied Sciences, Architectural Department

FEILDEN, M.B., JOKILEHTO, J., (1998). Management Guidelines for World Cultural Heritage Sites, ICCROM, Rome

SU, R., BRAMWELL, B., WHALLEY, A,P., (2018). Cultural Political Economy and Urban Heritage Tourism, Annals of Tourism Research, Vol 68, pp: 30-40

\section{INTERNET KAYNAKLARI}

http://www.kulturvarlikları.gov.tr/TR,44423/

dunya-miras-listesi.html (E.T.14.10.2017)

http://www.icomos.org.tr/Dosyalar/ICO-

MOSTR_0280118001353669454.

pdf(E.T.14.10.2017)

http://www.europanostra-tr.org/files/file/Farokonvansiyonu.pdf(E.T.14.10.2017)

http://www.Ecco-eu.org/fileadmin/assets/ documents/echy2018/Namur-Declar_ en.pdf(E.T.14.10.2017)

http://www.icomos.org.tr/Dosyalar/ICO-

MOSTR_0901543001353670596.

pdf(E.T.14.10.2017)

http://whc.unesco.org/en/list/357 (E.T.

26.12.2017) 